\title{
FEARLESSLY SWIMMING UPSTREAM TO RISKY WATERS: THE ROLE OF GEOGRAPHIC ENTRY IN INNOVATION
}

\author{
CURBA MORRIS LAMPERT \\ College of Business \\ 11200 S.W. $8^{\text {th }}$ Street \\ Florida International University \\ Miami, FL 33199 \\ E-Mail: curba.lampert@fiu.edu \\ Tel: (305) 348-4929 \\ MINYOUNG KIM \\ School of Business \\ 1654 Naismith Drive \\ University of Kansas \\ Lawrence, KS 66045 \\ E-mail: mkim@ku.edu \\ Tel: (785) 864-1856 \\ TIMOTHY DAVID HUBBARD \\ Mendoza College of Business \\ 352 Mendoza College of Business \\ University of Notre Dame \\ Notre Dame, IN 46556 \\ E-mail: thubbard@nd.edu \\ Tel: (574) 631-0802 \\ RAJA ROY \\ Martin Tuchman School of Management \\ 4025 Central Avenue Building \\ New Jersey Institute of Technology \\ Newark, NJ 07102 \\ E-mail: rroy@njit.edu \\ Tel: (973) 596-5854 \\ GEORGE LECKIE \\ Centre for Multilevel Modelling \\ Graduate School of Education \\ 35 Berkeley Square, Bristol \\ University of Bristol \\ United Kingdom BS8 1JA \\ E-mail: g.leckie@bristol.ac.uk \\ Tel: 00441173314215
}

We appreciate the insightful comments and suggestions from Guest Editor Reddi Kotha, the three anonymous reviewers, and our colleagues including Sharon Alvarez, Rajshree Agarwal, Sekou Bermiss, Laura Cardinal, Connie Helfat, Arun Kumaraswamy, Sumner La Croix, Gideon Markman, Chet Miller, Will Mitchell, Francisco Polidoro, Frank Rothaermel, Melissa Schilling, Deepak Somaya, PK Toh, Chris Tucci, Fred Walumbwa, Brian Wu, and Ed Zajac. We especially thank David Teece and Alain Verbeke. The authors also gratefully acknowledge the financial support provided by their respective institutions. 


\title{
FEARLESSLY SWIMMING UPSTREAM TO RISKY WATERS: THE ROLE OF GEOGRAPHIC ENTRY IN INNOVATION
}

\begin{abstract}
We examine the puzzling geographic pattern that shows firms entering countries with weak intellectual property rights (IPR) protection with their research and development (R\&D) activities. Geographic entry into weak IPR protection countries is at odds with conventional wisdom as such an environment erodes a firm's ability to appropriate from its innovations. We offer that while the well-established practice of spreading out a firm's value chain activities across a region has important implications for value creation, what remains unaddressed is the value appropriation aspect of such activities. We introduce a multilevel theory and maintain that operating regionally through commercialization activities (downstream activities) provides complementary assets to the upstream activities - specifically R\&D activities in a country within that region - with which focal firms can appropriate more from their innovations. We find that regional downstream commercialization activities can substitute for weak IPR regimes, thereby providing firms with an alternative mechanism for protecting their intellectual property in weak IPR countries.
\end{abstract}

Keywords: geographic entry, complementarities, innovation, $R \& D$, value appropriation, upstream and downstream activities 


\section{INTRODUCTION}

Innovation is a difficult process, demanding that firms keep pace with technological changes while avoiding overly repeating and exhausting recombinant opportunities (Fleming, 2001). Geographic entry into foreign markets through research and development (R\&D) activities can allow firms to access global resources to assist in their innovation processes (Almeida, 1996; Almeida and Kogut, 1999; Doz and Wilson, 2012; Florida, 1997; Frost, 2001; Jaffe et al., 1993; Nelson, 1993; Patel and Vega, 1999; Pearce, 1999; Zhao, 2006). An analysis by Goldman Sachs offers economic evidence that the global distribution of research and scientific activity is shifting, suggesting a 'changing and more global innovation landscape' (Gilman, 2010, p. 3). As new hubs of innovative activity are emerging, and across a range of industries-including automotive, electronics, IT consulting and services, networking and communication devices, pharmaceuticals, and semiconductors - presents an opportunity for firms to rethink where they want to invest their innovative activities (Gilman, 2010).

Recent instances of geographic entry into foreign countries through $R \& D$ activities by firms reflect the economic evidence. For example, Pfizer is investing \$14 million in Chile to launch a Center of Excellence in Precision Medicine (CEPM), which will focus on developing new genome-based diagnostic technologies for cancer (Leask, 2015). Sylvia Varela, president of Pfizer Oncology for Latin America, explains 'the work that will be done at CEPM will be on par with the best and most renowned research centers in the world' (Leask, 2015). Apple is investing \$1 billion in a new R\&D center in Vietnam, joining the high-profile firms of Samsung Electronics, Hewlett-Packard, and Panasonic, which have made significant investments in R\&D centers there as well (Maylay Mail Online, 2016; Tuyet, 2016). Intel chose Costa Rica to host its newest R\&D 'mega lab', which will develop new smartphones, tablets, laptops, desktops, and 
all-in-one computers for its global customers (Arias, 2015a, 2015b; Costa Rican Investment Promotion Agency, 2014).

A primary reason for studying the role of geographic entry in innovation has been to understand how firms can use geographic entry as a source of value creation. Geographic entry into foreign markets can allow firms the opportunity to potentially access resources to fuel their innovative processes, including new and diverse sources of knowledge (Almeida, 1996; Frost, 2001; Pearce, 1999), high-quality scientists, engineers, and designers (Florida, 1997; Zhao, 2006), different national innovation systems (Freeman, 1987; Lundvall, 1992; Nelson, 1993; Patel and Vega, 1999) and knowledge spillovers (Almeida and Kogut, 1999; Jaffe et al., 1993), many of which are only reachable by being in distinct, host locations (Birkinshaw, 2000; Cantwell, 1989; Dunning, 1998; Frost, 2001; Kogut, 1991). Returning to our aforementioned examples, a firm's geographic entry into the foreign markets of Chile, Vietnam, or Costa Rica can offer location-specific advantages leading to enhanced value creation for the firm.

However, the performance of a firm's R\&D investment is a joint function of value creation and value appropriation. In this light, what is striking about Chile, Vietnam, and Costa Rica is that they are all countries that do not have strong intellectual property rights (IPR) protection. As R\&D activities are subject to risks of knowledge leakage and threats of imitation from global exposure, firms may not be able to appropriate the economic return from the value they create in such countries (Teece, 1986). This makes the empirical patterns of geographic entry into the weak IPR protection countries all the more perplexing. Thus, in understanding the role of geographic entry in innovation there remains the unresolved question of how do firms appropriate the value they create from their $R \& D$ activities in such weak appropriability regime countries? 
In this paper, we seek an answer to this research question and attempt to explain the recent, puzzling geographic patterns that show firms entering their R\&D activities into countries with weak IPR protection. Geographic entry into weak IPR countries is at odds with conventional wisdom as such an environment erodes firms' ability to appropriate from their innovations. We combine the technology management literature's complementary assets framework (Mitchell, 1989, 1991; Teece, 1986; Tripsas, 1997) with the international management literature's regionalization theory and semiglobalization perspective (Ghemawat, 2003, 2005; Rugman and Verbeke, 2004, 2007) to develop a new theoretical model of the role of geographic entry in innovation. Joining the two streams of theories not only helps us to address the research question but also results in explanatory power gains from the cross-fertilization, which facilitates a new exchange in a now shared conversation across the technology management and international management literatures.

Toward this end, we first conceptualize geographic entry into a region as the regional configuration of complementary assets, or the geographic dispersion of a firm's value chain activities across countries within a region. With this conceptualization, we offer that while the well-established practice of spreading out a firm's value chain activities across a region has important implications for value creation, what remains unaddressed is the value appropriation aspect of such activities. We introduce a multilevel theory and maintain that operating regionally through commercialization activities (downstream activities) provides complementary assets to the upstream activities - specifically R\&D activities in a country within that region — with which the focal firm can appropriate more from its innovations. More specifically, we develop a framework that suggests that commercialization activities in the region help firms develop a firm-specific value appropriation capability that allows them to appropriate more from their 
innovation activities even in the countries within the region with weak IPR protections. We submit that regional downstream commercialization activities can substitute for weak IPR regimes, thereby providing the firm with an alternative mechanism for protecting its intellectual property in weak IPR countries.

We test our theory using a dataset of innovative activity in the global pharmaceutical industry encompassing 142 multinational enterprises (MNEs) operating in 118 countries within 18 geographic regions. This dataset accounts for all of the sample firms' drug commercialization activity and R\&D activity worldwide. We employ a cross-classified multilevel analysis to simultaneously account for the firm, country, and regional levels of analysis and answers calls for more multilevel research (Arregle et al., 2006; Cheng et al., 2009; Hitt et al., 2007; Peterson et al., 2012).

Our theory and findings contribute to the literature in three ways. First, we illuminate the role of geographic entry in innovation as the regional configuration of complementary assets from a value appropriation aspect. In doing so, we extend the extant literature on regionalization that has focused on the value creation aspect of complementary assets in creating values through the synergistic configuration. While important, the value creation aspect of the regional configuration of complementary assets may not be sufficient to address the puzzling pattern of R\&D investments into weak IPR countries. For this, we shed new light on the aspect of complementary assets in appropriating values from the perspective of regionalization and maintain that the regional configuration of complementary assets can provide an alternative mechanism for firms to protect their intellectual property in countries within that region with weak IPR protection and thus substitute for weak IPR regimes. As there have been few attempts to study how entry decisions can impact firms' subsequent behavior, this research directly 
responds to the call in the literature for researchers to 'cast a wider net than previous work on market entry...[with] more expansive research and theory' (JMS Special Issue Call for Papers, 2016). Our study provides evidence between geographic entry and firms' subsequent innovative behavior.

Second, we offer novel insights and contribute to the understanding of a relevant contemporary phenomenon—globalization. More specifically, our findings offer important nuances in understanding that despite the flood of exposure directed toward globalization through both the academic and popular press, firms' activities remain highly regionalized, making globalization semi at best. This research extends the work by regionalization scholars by showing a novel mechanism enabling and reinforcing the phenomenon of regionalization. More specifically, extending previous research that tends to exhibit path-dependency between similar activities, the current study shows that one set of a firm's activities act as a catalyst in igniting a different set of activities, thereby encompassing a more comprehensive set of activities in the region and thus reinforcing the process toward regionalization. We detail the theoretical mechanisms through which this influence occurs and offer an explanation for why firms that organize regionally could have greater breadth in activities, as such activities also benefit from cross-fertilization. We contribute new insights into how geographic regions may influence various firm activities — above and beyond what considering only countries can explain.

Finally, we make a methodological contribution to the management literature by proposing a cross-classified multilevel analysis for studying firms' geographic entry decisions. Countries nest within regions; however, MNEs move across country and regional borders seeking location-specific advantages. The cross-classified multilevel approach, unlike the 
traditional nested approach, can properly capture the mobility of MNCs across countries and regions, one of the fundamental building blocks of many theories in international business.

\section{THEORETICAL BACKGROUND}

In this research, our attention is on examining the role of geographic entry in innovation. We focus on geographic entry through the components of the value chain and, more specifically, through the upstream (R\&D processes) and downstream (commercialization processes) activities, as innovation includes not only the R\&D processes but also the commercialization processes in the launch of new products (Kim and Pennings, 2009). Scholars have applied the upstream/downstream framework to innovation research on strategic alliances (Baum et al., 2000; Koza and Lewin, 1998) as well as to intellectual human capital (Hess and Rothaermel, 2011). We believe that upstream/downstream framework is relevant in the current study, as we are investigating firms' R\&D entry into countries with weak IPR protection from the perspective of downstream complementary assets.

\section{Regionalization Theory and the Semiglobalization Perspective}

The region construct, defined as a grouping of countries in geographic proximity, offers new understanding as to how firms profit and has gained distinction in both international management and strategy literatures (Arregle et al., 2009; Arregle et al., 2013; Buckley and Ghauri, 2004; Cantwell, 2009; Dunning, 1998; Flores and Aguilera, 2007; Ghemawat, 2001, 2003, 2005; Kim and Aguilera, 2015; Rugman and Verberke, 2004, 2007, inter alia). To situate the theoretical positioning and importance of the region construct in the literature, we return to theories of the MNE. In one of the most seminal works on the theory of the MNE, Buckley and Casson (1976, p. 32) state a core premise that framed their theory as 'firms maximize profit in a world of imperfect markets'. In this global context, 'it is the combination of the exchange and the value- 
adding functions that will determine a firm's profitability' (Dunning, 2003, p. 109, italics in original).

Scholarly work on the exchange function identifies specific hazards that come with crossborder contractual and market failures. It is because of these failures that firms internalize their exchanges across countries (Buckley and Casson, 1976; Dunning, 1981; Dunning and Lundan, 2008; Rugman, 1981; Teece, 1975, 1981). In contrast, value adding functions are less about transaction costs economized through internalization and more about 'the common (organizational) culture of an integrated enterprise and the ease of coordination inside the firm, as compared with coordination through the market' (Teece, 2014, p. 10). MNEs invest across countries in both exchange and value adding functions to maximize profitability (Dunning, 2003). Moreover, 'even if transaction costs were zero... learning, co-creation, and orchestration functions would still need to be carried out... [and the] MNE is a vehicle designed to do so' (Teece, 2014, p. 22). As such, contemporary theories of the MNE view it as 'an island of (nonmarket) resource allocation orchestrated to enhance learning, value creation, know-how transfer, and value capture' (Teece, 2014, p. 22).

Recent scholarly work on investments by MNEs into imperfect regional markets offers fresh insights into theories of the MNE. More specifically, investments by MNEs into regions constitute a critical research area in the strategy literature and in the international management literature on location choices. Regionalization theory argues that firms can take advantage of geographic, cultural, administrative, and economic proximity within regions (Ghemawat, 2005). Moreover, 'these four factors are interrelated: Countries that are relatively close to one another are also likely to share commonalities along other dimensions...those similarities have intensified in the past few decades through free trade agreements, regional trade preferences and 
tax treaties, and even currency unification' (Ghemawat, 2005, p.100). Thus the benefits offered by regions are not just the sum of the countries within a region as the shared commonalities create synergies thereby elevating regional benefits further (Flores and Aguilera, 2007; Ghemawat, 2003; 2005; Kim and Aguilera, 2015; Rugman and Verbeke, 2004; 2007, inter alia). Similarly, recent economic evidence regarding the economic integration of markets reveals a state of incomplete market integration called semiglobalization, where markets are not completely isolated or completely integrated across borders (Ghemawat, 2003). The perspective of semiglobalization offers a challenge to the conversation currently held in both the academic literature and that of the popular press on globalization (Cairncross, 2001; Friedman, 1999, 2005), including the 'flat' world perspective (Friedman, 2005). Semiglobalization scholars argue that regions, as an intermediate degree of globalization, offer distinctive benefits to firms because the world's markets are imperfectly integrated across geographies (Ghemawat 2003, 2005; Rugman and Verbeke, 2004, 2007).

Further empirical evidence corroborates regionalization and semiglobalization. Rugman and Verbeke (2004) studied the activities of the 500 largest MNEs and found very few to be operating globally; rather, they found strong support of regionalization. Rugman (2005) offers more evidence that almost all MNEs are 'regional' rather than 'global'. Arregle et al. (2009) confirm a regional value adding effect on the foreign subsidiary location decisions of Japanese MNEs. More specifically, they determine that a firm's prior foreign subsidiary activity at the regional level determines the number of subsequent foreign subsidiaries in a country. The authors explain this finding as MNEs seeking regional agglomeration and arbitrage benefits between countries in the same region. Research by Arregle et al. (2013) also draws on the value adding function and demonstrates that MNEs' prior investments in a region impact their future 
investments to countries within that region. In other words, it is easier to redeploy prior investments made in a region to countries within the region (intra-region) rather than across regions (inter-region). Thus, these studies confirm regionalization and semiglobalization and the need for reaching beyond country-level analyses to include regional-level analyses for a more representative and comprehensive perspective of firms' strategic processes (Arregle et al., 2009; Arregle et al., 2013; Ghemawat, 2003, 2005; Qian, et al., 2013; Rugman, 2005; Rugman and Verbeke, 2004, 2007).

Regionalization and semiglobalization advance the literature's theories of the MNE. Understanding how firms operate regionally offers a new dimension to the answer to how 'firms maximize profit in a world of imperfect markets' (Buckley and Casson, 1976, p. 32). Moreover, regionalization offers fresh insights into the two functions—exchange and value adding - which determine a firm's profitability (Dunning, 2003, p. 109). Recent research on the regional value adding effect makes an important contribution to literature in understanding how firms maximize profit across imperfect markets (Arregle et al., 2009; Arregle et al., 2013). However, maximizing profit requires consideration not only of value creation aspects but also of value appropriation aspects (Kim, 2016). To our knowledge, no research to date has evaluated the value appropriation considerations of regionalization. Thus, regionalization and semiglobalization open up an additional area of research that requires new theorizing, new mechanisms, and new statistical techniques to account for country-level and regional-level analyses. In this research, we attempt to address the gap in regionalization on value appropriation. More specifically, we argue that the geographic dispersion of value creating complementary assets allows for value appropriation. 


\section{The Complementary Assets Framework}

In his seminal paper, Teece (1986) addresses key strategic issues surrounding the appropriation of technological innovations. He offers that there are two ways for firms to appropriate the value of their innovations. First, he argues that downstream complementary assets (DCAs) - the assets dedicated to 'marketing, competitive manufacturing, and after-sales support' — help the possessor to appropriate the value created by those products (p. 288). Second, Teece also argues that the appropriability regime, or IPR protection of an environment, has an impact on the ability of innovators to appropriate the value from their technological innovations. One of the insightful points Teece makes in this groundbreaking paper is that the abovementioned two mechanisms are in a substitutional relationship. The substitutional relationship identifies that when the legal protection of IPR is weak, an alternative mechanism is required for innovators to profit from their innovations (Teece, 1986). Therefore, when the appropriability regime is strong (where the innovation has an institutional protection), 'firms could rely on licensing and other contractual arrangements to extract rents from their innovation without access to such assets' (Pisano, 2006, p.1123). Thus, the substitutional relationship underscores that the two mechanisms are intrinsically interdependent such that one cannot separate the DCAs from the IPR environment in which they are operating (Teece, 1986). To put it another way, to correctly understand the implications of the DCAs, one must also understand the IPR environment.

In developing our theory further, we now turn to the complementary assets framework, derived from Teece’s (1986) pioneering paper (Mitchell, 1989, 1991; Teece, 1986; Tripsas, 1997). The framework provides a larger theoretical base that we use to conceptualize geographic entry into a region as the regional configuration of complementary assets. The framework posits that in 
studying the innovation process, placing so much emphasis on the upstream activities (such as $\mathrm{R} \& \mathrm{D})$ overlooks the downstream activities (such as commercialization). Yet, it is in the downstream activities where firms actually appropriate the value for their R\&D efforts. Profitably engaging in upstream activities requires the development of downstream complementary assets such as specialized distribution channels and dedicated sales and service operations. As Teece explains, '[i]n almost all cases, the successful commercialization of an innovation requires that the know-how in question be utilized in conjunction with other capabilities or assets' (1986, p. 288).

Teece (1986) differentiates between DCAs as generic, specialized, and co-specialized, determined by how specific the DCAs are to the innovation. The complementary assets framework focuses on specialized and co-specialized ${ }^{i}$ DCAs, recognizing that although these assets build over time and are expensive to develop, commercializing with them is more valuable to the firm and can translate to a unique advantage, a barrier to imitation and a way to appropriate from innovation (Mitchell, 1989, 1991; Rumelt, 1984; Teece, 1986; Tripsas, 1997).

Research on DCAs for value appropriation has been vibrant. For example, Mitchell's (1991) work in the medical diagnostic imaging industry indicates that firms that commercialize their technological innovation with specialized DCAs achieve greater performance, measured in both market share and survival, thereby supporting the value appropriation aspect of complementary assets. Similarly, Tripsas (1997) investigates the role of specialized DCAs, and specifically, that of a specialized manufacturing capability, a sales and service network, and a font library in the typesetting industry. She concludes that the firm's ability to appropriate the benefits from its technological innovations through specialized DCAs plays a critical role in its performance. Supporting this argument further is Polidoro's (2013) work that shows that firms that actively build up their DCA of a well-established reputation, obtained through third-party 
certifications, will thwart competition from rivals, thereby allowing the firm to appropriate more value from its innovations. Likewise, Wu et al. (2014) highlight the importance of DCAs as powerful resources (pipes) that can be used to appropriate value from firms' technological innovations. The authors elucidate that during the transition to digital photography, Kodak leveraged its film-based complementary assets to maximize its returns across its innovations. More specifically, by using its strong network of retail relationships, 'Kodak was able to persuade many retailers to add the Photo CD system to their photofinishing facilities' (p. 1262). Moreover, Kodak also promoted retailers' adoption of their APS system, producing higher quality prints and self-service kiosks. Thus, Kodak's DCAs were supporting both its digital and print innovations, assuring that 'Kodak would still be able to make money from consumables like photo paper and services' (p. 1262).

It is well-documented in the literature that in addition to the value appropriation aspect of complementary assets, there exists the synergistic- and thus value creation aspect of complementary assets. Complementarity not only brings greater appropriation but also brings opportunities for synergies, ${ }^{\text {ii }}$ where the whole is greater than the sum of its parts. For example, Arora and Gambardella (1990) find that a firm that uses external linkages to assist in combining upstream and downstream areas of the value chain creates complementarities for itself and, moreover, if the external links access distinct knowledge, the links are synergistic to one another. Helfat (1997) finds that when firms need to augment their upstream R\&D, it is those with greater DCAs that carry out more upstream R\&D activity, crediting the effect to complementarity in the value chain. Hess and Rothaermel (2011) find that integrating upstream knowledge from star scientists with downstream alliances draws complementarities by linking knowledge from one segment of the value chain to another. Ceccaggnoli et al. (2010) find downstream activities with 
high levels of co-specialized complementary assets to be complementary to upstream R\&D activities.

\section{Regionalization as Configuration of Complementary Assets}

In the Introduction, we define geographic entry into a region as the regional configuration of complementary assets, or the geographic dispersion of a firm's value chain activities across countries within a region. As the main focus of our paper is value appropriation, we center on downstream activities (commercialization activities) — the complements to upstream activities (R\&D activities) — in consideration of their substitutional relationship with the IPR regime.

Building on the aforementioned research, DCAs help innovators appropriate the value from their innovations. Co-specialized DCAs - those most specific to the innovation — can include idiosyncratic manufacturing knowledge and facilities, regulatory knowledge, a dedicated sales force with a strong network of relationships, and an established reputation (Helfat and Lieberman, 2002; Mitchell, 1989, 1991; Stieglitz and Heine, 2007; Teece, 1986). In addition to being specific to the innovation, co-specialized DCAs can be specific to particular locations, and consequently are useful only in a restricted range of environments (Helfat and Lieberman, 2002). As expounded in the literature of regionalization, the upstream activities and the downstream activities in the context of regionalization tend to be bilaterally specialized (Ghemawat, 2005). As such, the investment of downstream activities into a region is understood as the regional configuration of co-specialized DCAs.

Returning now to the insightful point that Teece (1986) delineates in his paper, we advance our main thesis that the regional configuration of co-specialized DCAs is in a substitutional relationship with the IPR environment. More specifically, when operating in a weak IPR protection environment, firms must have an alternative means to protect their IPR and 
require strong co-specialized DCAs. On the flip side, when operating in a strong IPR protection environment, an alternative mechanism may not be required (Pisano, 2006; Teece, 1986). In summary, because the co-specialized DCAs and the IPR environment in which they are operating in are so intrinsically intertwined, any implications of value appropriation must take into account the two mechanisms simultaneously.

\section{HYPOTHESES}

Before we advance our hypotheses on the value appropriation aspects of the regional configuration of co-specialized DCAs, we discuss their value creation implications as the performance implications of an R\&D investment is a joint function of value creation and value appropriation.

\section{Co-specialized DCAs and Value Creation}

Aggregation and arbitrage possibilities across the region through the regional configuration of co-specialized DCAs extend to the firm an expanded geography for value creation opportunities. Regions offer shared commonalities as the physical continuity and proximity limits their diversity; yet they enjoy economic cooperation, essential historic ties, government support, and institutional and cultural similarity across countries (Ghemawat, 2003, 2005, 2007; Rugman and Verbeke, 2004, 2005, 2007). Geographic proximity is a key factor for growing regionalization; spatial aspects to the transmission of information and knowledge in economic exchange have long been recognized (Buckley and Ghauri, 2004; Ghemawat, 2001, 2003, 2005; Rugman and Verberke, 2004). Geographic proximity also plays an important role in opportunity identification and evaluation, and is particularly important in the transmission of 'soft' information, ${ }^{\text {iii }}$ which transmits through relationships in a local geographic area (Petersen, 2004; Petersen and Rajan, 2002). The influence of geographic proximity on investment opportunity decisions has been 
demonstrated in mutual fund (Coval and Moskowitz, 2001), venture capital (Sorenson and Stuart, 2001), alliance (Reuer and Lahiri, 2013), and acquisition investments (Chakrabarti and Mitchell, 2013). Thus, the firm's presence in the region through its regional configuration of cospecialized DCAs allows it to exploit regional synergies and differences. As such, a region has important implications for value creation and is well established (Arregle et al., 2009; Arregle et al., 2013).

\section{Co-specialized DCAs and Value Appropriation}

While important, the value creation aspect of the regional configuration of co-specialized DCAs may not be sufficient to address the puzzling patterns of R\&D investments into weak IPR countries. Theory dictates that maximizing profit requires consideration not only of value creation aspects but also of value appropriation aspects. Teece explicates the value appropriation aspect of complementary assets in his (1986) generative work. Moreover, regionalization theory and the semiglobalization perspective offer a new dimension to answer the question of how 'firms maximize profit in a world of imperfect markets' (Buckley and Casson, 1976, p. 32). Accordingly, if the regional configuration of co-specialized DCAs matters for value creation, what is the value appropriation aspect of such activities?

Our clubbing together the two streams of theories from the technology management literature's complementary assets framework (Mitchell, 1989, 1991; Teece, 1986; Tripsas, 1997) with the international management literature's regionalization theory and semiglobalization perspective (Ghemawat, 2003, 2005; Rugman and Verbeke, 2004, 2007) offers two new insights into the value appropriation aspect of the regional configuration of co-specialized DCAs. First, the regional commonalities and consequent regional nature of firms' operations enable firms to link their upstream and downstream activities located in different counties within a region. This 
linkage is necessary to realize the complementarities between the upstream activities and the downstream activities with which the firm can appropriate the value it creates in the region. Second, regionalization implies that the DCAs are dispersed regionally, which makes them difficult for competitors to replicate. Together, these two insights underscore that the regional configuration of co-specialized DCAs enables firms to develop a firm-specific value appropriation capability with which they can better appropriate the value they create through the innovation process. We now discuss in more detail the mechanisms behind these two insights.

Teece's (1986) motivation in his seminal paper was to provide a theoretical foundation to understanding the real world frustration experienced by innovators who are unable to appropriate from their technological innovations. He offers that in most cases in order for innovators to profit from their upstream activities they must also develop downstream complementary assets. He details the importance of linking the upstream activities with the downstream activities for value appropriation. By applying his insights to the regional context, we maintain that regionalization theory and the semiglobalization perspective provide the theoretical foundation to better understanding the geographic space in which the link between the upstream activities and the downstream activities is established. The shared commonalities within a region provides opportunities for regional aggregation and arbitrage, making it more likely for the firms to organize their value creating activities to be more connected within a region (intra-region) than across regions (inter-region) (Ghemawat, 2003, 2005; Rugman and Verbeke, 2004, 2007). These linked value creating activities within the region would, in turn, provide the value appropriation mechanisms with which the firms can capture the value they create through innovations. In sum, the two streams of theories together delineate how the upstream activities and the downstream activities, located in different countries within a region, work in tandem for value appropriation. 
In addition to providing the geographic space in which the link between the upstream activities and the downstream activities is established, regions also provide an additional advantage for value appropriation. As Teece (1986) explains, the harder it is for competitors to replicate the DCAs, the bigger the advantage to the innovator. Consistent with the theoretical arguments proposed above regarding value creation, by operating regionally the firm likely has its co-specialized DCAs labyrinthically spread out over multiple countries in its efforts to exploit regional synergies and differences. One of the important mechanisms behind the regional configuration of co-specialized DCAs as a source of value appropriation is the geographic dispersion of DCAs across countries within the region. Co-specialized DCAs labyrinthically spread out over multiple countries increases the causal ambiguity and uniqueness of the firm's activities and assets, and thus creates greater barriers to their imitation (Kim, 2013).

To this point more specifically, locating all the co-specialized DCAs in a country would be ideal to maximize the benefit from the synergistic facet and thus value creating aspect of DCAs from the complementary asset framework. However, collocating all the value creating cospecialized DCAs in a country would make them vulnerable to potential imitation, thus limiting the opportunity to appropriate the value created through the innovation activities (Teece, 1986), because "[v]alue appropriation presupposes that the owner can exclude non-owners from using or destroying attributes to which he holds property rights' (Foss and Foss, 2005: 544, italics in original). As such, geographic dispersion of the co-specialized DCAs across multiple countries will help firms prevent imitation, since it will increase causal ambiguity and uniqueness and thus create isolating mechanisms (Kim, 2016; Lippman and Rumelt, 1982; Mahoney and Pandian, 1992; Rumelt, 1984). However, dispersing the co-specialized DCAs all over the world may not be ideal since this would make it difficult to reap the synergies between the co-specialized DCAs 
that are too far away from each other. Therefore, we posit that regionalization can be an ideal compromise between these two countervailing forces. More specifically, on the one hand, pure domestic configuration may be ideal for synergy but not for capturing it exclusively. On the other hand, full globalization may be optimal for preventing imitation but not for synergies as it incurs non-trivial costs including searching and coordination (Grant, 1996; Sorenson and Stuart, 2001). In fact, the foregoing discussion can provide a new and complementing explanation for the prevalent patterns of regionalization rather than globalization found by many studies. Namely, as performance of an R\&D investment is a joint function of value creation and value appropriation, regionalization could provide an ideal extent of geographic scope for internationalization where firms can incorporate the two countervailing forces: the need for geographic proximity to enjoy value creation from the co-specialized DCAs versus the need for geographic dispersion to appropriate the value created through innovations.

So, how do co-specialized DCAs in a region help firms to develop a firm-specific value appropriation capability and thus appropriate more from their innovation activities? We maintain the regional configuration of co-specialized DCAs enables firms to develop a firm-specific value appropriation capability with which they can better appropriate the value they create through the innovation process. This capability is firm specific because the configuration is idiosyncratic to the firm organized in the region. The firm-specific value appropriation capability makes it difficult for competitors to imitate, providing temporal monopoly of the firm's innovation. The longer firms can impede their competitors, the longer they sustain their competitive advantage (Kim, 2013). Therefore, we expect that firms with prior commercialization activity in a region will show a higher willingness to engage their R\&D activities in a country within that region as their regional configuration of co-specialized DCAs affords them a greater ability to appropriate 
more from their innovations. Based on the preceding discussion, we predict the following baseline hypothesis:

Hypothesis 1: A firm's prior commercialization activity in a region positively relates to its $R \& D$ activity in a country within that region.

\section{The Appropriability Regime}

As we previously advanced in our theoretical background section, the complementary assets framework argues that the appropriability regime, or IPR protection of an environment, also has an impact on the ability of innovators to appropriate their technological innovations (Teece, 1986). When the appropriability regime is strong (where the innovation has protection), 'firms could rely on licensing and other contractual arrangements to extract rents from their innovation without access to such assets' (Pisano, 2006, p.1123). However, when the legal protection of IPR is weak, complementary assets are required for innovators to profit from their innovations (Teece, 1986). In other words, when operating in an environment with weak IPR protection, firms must have an alternative means to protect their IPR. In short, 'strategy is contingent on the appropriability regime' (Pisano, 2006, p. 1123).

When investing in R\&D activities in foreign countries with weak IPR protection, and where misappropriation hazards are high, firms can substitute the weak IPR protection with their firm-specific value appropriation capability. In other words, for environments with weak IPR protection, the firm-specific value appropriation capability can serve as an alternative mechanism to capture the economic returns from innovation for a firm. Consequently, the firm's R\&D activities in countries within the region with weak IPR protection can benefit more from its regional configuration of co-specialized DCAs, as there is more potential for the downstream activity in the region to compensate for the countries' weak IPR protection. We therefore expect that the positive effect we predict in our first hypothesis, where firms with prior 
commercialization activity in a region will show a higher willingness to engage their R\&D activities in a country within that region as their regional configuration of co-specialized DCAs affords them a greater ability to appropriate more from their innovations, will be stronger for those focal host countries within the region in which IPR protection is weak. The preceding discussion leads to the research hypothesis:

Hypothesis 2. A firm's prior commercialization activity in a region can substitute for IPR protection. More specifically, we expect that the effect of a firm's regional commercialization activity on its $R \& D$ activity in a country within that region to be greater in the countries with weaker IPR protection.

\section{DATA AND METHODS}

\section{Sample}

We test our hypotheses with a longitudinal dataset on the innovative activities of 142 leading firms from the global pharmaceutical industry during the time period of 1997 to 2006 . The global pharmaceutical industry is an ideal setting for this research because: (i) it is a decidedly global industry; (ii) it deals with innovation and has the need to protect IP; and (iii) it has international commercialization and R\&D activities. As such, it is an industry in which relevant aspects of our theory are empirically observable.

We identified the leading players in the global pharmaceutical industry by compiling lists published annually by private research companies such as IMS Health, the industry's trade associations such as the Pharmaceutical Research and Manufacturers of America, popular press outlets such as Forbes, and the industry's trade journals such as Pharmaceutical Executive. We include divisions and subsidiaries with parent firms using Who Owns Whom (published by GAP Books in association with Dun \& Bradstreet), The Directory of Corporate Affiliations, LexisNexis, and the specific firm's website. We confirmed the involvement of each firm in active 
drug discovery and development and excluded any not active or focused on reformulations or generics. Our global sample includes firms with headquarters in 18 countries.

As noted in our theoretical background section above, a region is defined as a grouping of countries in geographic proximity (Ghemawat 2003, 2005; Rugman and Verbeke, 2004; 2005; 2007 , inter alia). We follow up the construct of a region with the empirical measure provided by Arregle et al. (2009, p. 88, italics added) with a 'geographical conceptualization of a region, in which the physical continuity and proximity among countries of the grouping is emphasized.' Likewise, the geographical definition of a region and its emphasis on physical continuity and proximity is accentuated in the literature for how firms organize their international strategy (Buckley and Ghauri, 2004; McNamara and Vaaler, 2000; Rugman and Verbeke, 2004, 2007), and how doing so promotes increasing trade, investment linkages, and convergence in practices (Ghemawat, 2001, 2003, 2007; Khanna et al., 2006). We define our regions using the United Nations Statistics Division's (UNSD) region classification system. ${ }^{\text {iv }}$ Our use of this classification is consistent with empirical research on semiglobalization (Arregle et al., 2009; Arregle et al., 2013). For information on firms' commercialization and R\&D activities, we utilize the AdisInsight database (Danzon et al., 2005; Girotra et al., 2007). Our dataset includes location information on every commercialization and R\&D project for our sample of firms, worldwide. We also use the Liu and La Croix (2015) index of property rights in pharmaceutical inventionsthe Pharmaceutical IP Protection (PIPP) Index. We employ Compustat, annual reports, and trade publications to obtain financial data.

To ensure appropriate understanding of geographic entry and innovation from the practitioner's perspective, we complement our archival data efforts with interviews of global pharmaceutical scientists and executives, FDA administrators, and health care providers 
including doctors and pharmacists. The interview process is critical to our thinking of how to approach the study. Our sample firms were operating in 118 countries across 18 regions. Table AI in the Appendix lists the countries and their regions.

As done in past management studies of geographic entry into foreign markets, we take a five-year window approach and choose to use two periods (1997-2001 and 2002-2006) to assess the variables (e.g. Arregle et al., 2009; Arregle et al., 2013). That is, we assess our independent variables during the early period and measure our dependent variable during the later period. This accounts for the length of time it takes for firms to develop new R\&D activities in a foreign host country, and matches what we saw coming from the interview process. As a robustness check, a three-year window approach also yielded consistent results. We also removed observations in each firm's home country and home region.

\section{Dependent Variable}

$R \& D$ activity of a firm in a country. We use the AdisInsight database to obtain geographic entry into foreign markets, or internationalization, information on our sample firms' R\&D projects. The R\&D process includes all projects across discovery (preclinical) steps and development (clinical) steps (Girotra et al., 2007; Henderson and Cockburn, 1996; Hill and Rang, 2012; Sosa, 2009, 2011). Figure 1 provides a schematic illustration of the R\&D (upstream) and commercialization (downstream) activities in the global pharmaceutical industry. We incorporate all projects across all the steps that comprise the R\&D process including the preclinical step, along with the three clinical steps of phases I, II, and III. We measure the geographic entry of R\&D activity of a firm in a country as a binary indicator where 0 indicates no geographic entry of R\&D activity in a particular country and 1 indicates that the firm had geographic entry of R\&D activity in that country. 
Insert Figure 1 about here

\section{Independent Variables}

Prior commercialization activity of a firm in a region. To test the influence that a firm's prior commercialization activity in a region has on a firm's subsequent internationalization of R\&D activity in a foreign host country in that region, we again use the AdisInsight dataset. To measure whether the firm had commercialization activities in a region, we observe if the focal firm had launched a drug in the region. We take a dichotomous approach in the construction of this variable because we theorize on the implications of the presence of the prior commercialization activity, not on the implications of the changes in the extent of prior commercialization activity. We create a variable equal to 1 if the firm had launched a drug in the region in the prior period, 0 otherwise.

Intellectual property right protection. We use Liu and La Croix's (2015) cross-country index of IP rights - the Pharmaceutical IP Protection Index (PIPP) - to assess the intellectual property rights protection in a region. This index is appropriate to test our hypotheses because it is used specifically to measure protection in pharmaceutical inventions. It is a comprehensive index that 'incorporates five types of property rights in pharmaceuticals; six statutory measures of enforcement; and adherence to three international agreements providing for the grant and enforcement of rights to foreigners' (Liu and La Croix, 2015, p. 206). We first weight the original PIPP index with each country's region-relative gross domestic product (GDP) in order to take into account the country's economic importance in the region (Arregle et al., 2013; Hejazi, 2007). We then calculate the regional-level variable as a mean of the GDP-weighted PIPP 
indices of the countries in the region. Higher levels of the index indicate more IPR protection and lower appropriation hazards.

\section{Control Variables}

We control for a number of firm-, regional-, and country-level variables: first, firm size, measured as the natural log of firm assets; second, firm's slack resources, measured as the current ratio — the firm's current assets divided by their current liabilities; third, firm's R\&D intensity (Arregle et al., 2013); and fourth, firm's total R\&D activity, which we measure as the number of drug discovery and development activities of the firm.

We also control for three variables that account for the firm's prior experience at the regional- and country-levels (Arregle et al., 2013; Lu, 2002): first, whether the firm engaged in commercialization during the prior period in a particular country; second, whether the firm engaged in R\&D activity in the prior period in a particular country, which is a lagged dependent variable; and third, whether the firm engaged in $R \& D$ activity overall in the region during the prior period. These three variables also control for potential sequences or entry orders between R\&D activities and commercialization activities.

Finally, we control for four country-level variables: first, the patenting activity of a country, employing the natural logarithm of the number of patent applications in the country (World Bank, 2015), which represents the overall R\&D activity within the country even beyond the pharmaceutical industry; second, the growth of gross domestic product (GDP) in the country to determine the potential desire to capture $R \& D$ benefits in fast-growing countries (Arregle et al., 2013); and third, a country's total R\&D activity of the pharmaceutical industry in that country employing the number of drug discovery and development activities in the country, to account for countries that have a higher base rate of pharmaceutical knowledge. Table I lists the 
constructs and measurements. We lagged commercialization activities, R\&D activities, R\&D intensity, and firm size variables in order to appropriately capture the causal relationship.

\section{Insert Table I about here}

\section{Analysis}

We use cross-classified, multilevel logistic regression to analyze firms' decisions to enter into R\&D activity in each country within a region. We use logistic regression because the dependent variable is binary. We use multilevel models with four levels as the data exhibit firm-, regional-, and country-level clustering; failure to account for such clustering typically leads to spuriously precise regression coefficients and incorrect inferences (Goldstein, 2011; Raudenbush and Bryk, 2002; Snijders and Bosker, 2012). We specify cross-classified rather than traditional hierarchical multilevel models as each firm operates across multiple countries and regions rather than being nested within a single country and region (Leckie, 2013). More specifically, as shown in Figure 2, unlike countries that are nested within regions, firms can invest not only in their home countries and regions (e.g., Firms 1 and 3) but also in other countries outside their home regions (e.g., Firms 2 and 4). Maximum likelihood estimation of these models is computationally infeasible; therefore, we fit all models by Markov Chain Monte Carlo (MCMC) methods. See Appendix A for further details.

Insert Figure 2 about here

\section{RESULTS}

Table II provides descriptive statistics and correlations. We test for multicollinearity between our independent variables using variance inflation factors and a condition number. The mean 
variance inflation factor is 1.70 and the highest individual value is 2.77 -both below the cutoff of 10 (Cohen et al., 2013). The condition number in our sample with our independent variables was 8.60 , well below the cutoff of 30 (Cohen et al., 2013). These tests indicate that there is no evidence that multicollinearity might have affected the analysis.

Insert Table II about here

We provide the results of our cross-classified multilevel logistic regression models in Table III. Model 1 of Table III shows the results for a set of control variables only. Models 2 and 3 provide results to test Hypotheses 1 and 2, respectively.

Insert Table III about here

Hypothesis 1 predicts that prior commercialization activity of a firm in a region would positively relate to subsequent $R \& D$ activity within a focal host country within that region. The results in Model 2 of Table III show that there is not a statistically significant positive relationship ( $\beta=0.03$, n.s.). Thus, there is no support for Hypothesis 1 .

Hypothesis 2 predicts that the positive effect of prior commercialization activity in a region will be stronger when IPR regime is weak. To test this hypothesis, we first create a region-relative GDP-weighted PIPP by subtracting the GDP-weighted PIPP of regions from that of countries. We then split the sample into four groups using the quartiles of the region-relative GDP-weighted PIPP and specify an interaction term between the quartile groups and the prior commercialization activity in a region. ${ }^{\mathrm{v}}$ Model 3 shows the results for the interaction analysis. The results reveal a positive relationship between the effect of prior commercialization in a region in the first quartile group $\left(Q_{1}\right)$ (i.e., the lower $25 \%$ with the weakest IPR) $(\beta=0.37, p<$ 
0.10 ), suggesting that the effect of prior commercialization activity in a region is positive in the countries with the weakest IPR. More specifically, in the first quartile group, presence of a firm's prior commercialization activities in a region would change the odds that the firm has $\mathrm{R} \& \mathrm{D}$ activities in a country within the region by a factor of 1.45 . The coefficient of the interaction term with the second quartile group $\left(Q_{2}\right)$ is negative but is not statistically significant $(\beta=-0.09$, n.s.), suggesting that the effect of prior commercialization activity in the second quartile group is smaller than that of the first quartile group, but the difference is not statistically significant. Lastly, the coefficients of the interaction terms with the third and fourth quartile groups $\left(Q_{3}\right.$ and $\left.Q_{4}\right)$ are negative and statistically significant $(\beta=-0.61, p<0.05)$, suggesting that the effects of prior commercialization activity in the third and fourth quartile groups (i.e., the higher $50 \%-75 \%$ and $75 \%-100 \%$ with the high and highest IPR, respectively) are smaller than that of the first quartile group with statistically significant differences. More specifically, in the third and fourth quartile groups, respectively, presence of a firm's prior commercialization activities in a region would change the odds that the firm has R\&D activities in a country within the region by a factor of 0.79. In sum, the results of the interaction analysis in Model 3 support Hypothesis 2 in that the effect of prior commercialization activity in a region is positive in the countries with the weakest IPR and becomes smaller as the IPR regime becomes tighter, corroborating the substitution effect between the IPR regime and firm-specific appropriation capability.

The nonsupport for Hypothesis 1 could be due to the intrinsic moderating effect of the IPR protection on the relationship between a firm's prior commercialization activity in a region and its R\&D activity in a country. The coefficients of the interaction terms in Model 3 of Table III become smaller and eventually turn negative as the IPR protection level increases. This pattern of changes in the coefficients of the interaction terms suggests that marginal effects of the 
prior commercialization activity could have different signs across the four quartile groups. As such, when put together in Model 2 of Table III without considering the implications of changing marginal effects, each of the countervailing marginal effects across the four quartile groups would cancel each other out, making the main effect coefficient indifferent from zero.

The abovementioned empirical explanation of the nonsupport for Hypothesis 1 is also in line with the theoretical foundation of our paper where we underscore the intrinsic substitutional relationship between the firm-specific value appropriation capability and the IPR regime of an environment. More specifically, when not explicitly considering the substitutional relationship, as in Hypothesis 1, the theoretical implications of the firm-specific value appropriation capability can be blurred or undetectable. However, the true theoretical implications of the firm-specific value appropriation capability are apparent when we explicitly consider the substitutional relationship in Hypothesis 2. In sum, although Hypothesis 1 is a necessary stepping stone, Hypothesis 2 is our main hypothesis as it subsumes the substitutional relationship and full theoretical logic of our paper. As such, non-support for Hypothesis 1 and support for Hypothesis 2 corroborates our main thesis.

\section{Robustness Checks}

We conducted four robustness checks to examine the sensitivity of the results in our primary analyses. First, in addition to the interaction terms specified in Model 3 of Table III, we conducted a subgroup analysis in each of the four-quartile groups. That is, we ran four separate cross-classified logistic regressions. This subgroup analysis allowed for the control variables in our models to vary from group-to-group. The results of these analyses demonstrated results consistent with our primary analyses. 
Second, in addition to the five-year window for the period, we specified a three-year window for the period. Specifically, the three-year periods covered 1997 to 1999, 2000 to 2002, and 2003 to 2005 . Using three-year windows as a robustness check increases the confidence that neither the specific five-year windows we used in our primary analyses nor the actual size of the window drives our results. These analyses demonstrated substantively similar results.

Third, we conducted the same analysis with the firm commercialization activity as a dependent variable. The results of this analysis show positive interactions between the prior commercialization activities and IPR protection. This overall trend—with the new dependent variable - shows a complementary rather than a substitutionary relationship between the prior commercialization activity and IPR protection. As such, this shows an entirely different mechanism at play (complementarities); in other words, these results are in line with the traditional understanding that prior experiences in a strong IPR regime predict higher likelihood of future investment in the same activities. Therefore, we believe that this result highlights an important distinction between our findings and, thus, the results further corroborate the main thesis of the current study that a focal firm's downstream complementary assets (i.e., prior commercialization activity) can help the firm develop a firm-specific appropriation capability for its upstream activity (i.e., R\&D activity), which it can substitute for a weak IPR regime.

Lastly, we consider that our primary independent variable, a firm's regional commercialization, is potentially endogenous (Antonakis et al., 2010). We consider and assess this condition by running a propensity score matching analysis (Guo and Fraser, 2010). Propensity score matching estimates the effect of a treatment—regional commercialization—by utilizing a set of covariates that predicts receiving the treatment (Guo and Fraser, 2010) ${ }^{\mathrm{vi}}$ In our case, we match the country to a number of firm-level controls: liquidity, R\&D intensity, size, 
international innovative activity, and regional R\&D activity. We use a minimum number of four matches per observation and a logit model for the treatment. The results show prior regional commercialization has an average treatment effect of $0.06(p<0.01)$ on the presence of R\&D activity within a country. This provides support for an overall influence of prior regional commercialization on the presence of R\&D within a country. In addition, as we maintain, more nuanced relationships occur if we consider different levels of IPR regimes. Unfortunately, propensity score matching does not allow for interactions. Therefore, we split the sample into the four quartile groups of the PIPP index, to test for effects across different levels of IPR protection. After doing this, we continue to see positive and statistically significant effects across low $\left(Q_{1}\right)(0.08, p<0.01)$, moderate low $\left(Q_{2}\right)(0.08, p<0.01)$, moderate high $\left(Q_{3}\right)(0.05, p$ $<0.01)$, and high $\left(Q_{4}\right)(0.06, p<0.01)$ — with the highest effects seen at low levels of IPR protection.

\section{DISCUSSION}

The extant studies on regionalization have largely focused on the value creation aspects of complementary assets. Adding and thus extending the literature, we attempt to understand the value appropriation aspect of such activities. Toward this end, we introduce the value appropriation aspects of regionalization by illuminating that the regional configuration of firms' value chain activities can provide complementary assets with which firms can appropriate more from their innovations. Specifically, we advance a framework suggesting that commercialization activities in a region help firms to develop a firm-specific value appropriation capability, thereby allowing them to appropriate more from their innovation activities even in the countries within the region with weak IPR protections, as the firm-specific value appropriation capability is in a substitutional relationship with the IPR environment. 
Returning to the examples given in our Introduction, we discussed firms' geographic entry into the foreign markets of Chile, Vietnam, and Costa Rica through upstream activitiesspecifically R\&D — and how these environments were especially risky for knowledge leakage and threats of imitation as all of these countries do not have strong IPR protections. With this research, we offer an answer to the puzzling empirical pattern of geographic entry. Our theory and results identify an alternative mechanism with which firms can protect their intellectual property in weak IPR environments. Thus, some firms really are fearlessly swimming upstream to risky waters.

\section{Theoretical Implications}

In this paper, we examine the role of geographic entry in innovation. Although scholars have explored entry decisions for decades, research on the relationship between entry and innovation is scarce (Zachary et al., 2015). Our theoretical analysis combines the technology management literature's complementary assets framework (Mitchell, 1989, 1991; Teece, 1986; Tripsas, 1997) with the international management literature's regionalization theory and semiglobalization perspective (Ghemawat, 2003, 2005; Rugman and Verberke, 2004, 2007) to develop a new theoretical model and predictions on the role of geographic entry in the regional configuration of complementary assets in innovation. Researchers rarely combine these two streams of theories as they largely address separate audiences. Thus, our illumination of unrealized theoretical synergies by joining the two streams of theories together results in greater explanatory power and a new, shared conversation between a larger swath of researchers across the international and technology management literatures. Our study offers several theoretical implications.

We extend the extant literature on regionalization that has focused on the value creation aspect to now include the previously unaddressed value appropriation aspect. For this purpose, 
we distinguish and contrast two aspects of complementary assets. The first underscores a synergistic facet and thus value creating aspect of complementary assets. The second is the value appropriation aspect of complementary assets expounded in Teece's (1986) seminal work. We theorize on the downstream activities (i.e. commercialization activities) in a region and the subsequent upstream activities (i.e. $R \& D$ activities) in a country within that region. We maintain that operating regionally through commercialization activities provides complementary assets to the R\&D activities with which firms can appropriate more from their innovations. We concentrate on the role of the regional configuration of co-specialized DCAs in assisting firms to develop a firm-specific value appropriation capability, in consideration of its substitutional role in weak appropriability regimes. From this perspective, our non-finding for Hypothesis 1 is, in fact, in line with the insightful points made by Teece (1986) in his groundbreaking paper, where he delineates the substitutional relationship between DCAs and the IPR environment. As such, since the DCAs cannot be separated from the environment in which they are operating, any theoretical argument must recognize the intrinsic interdependence between the two mechanisms for value appropriation.

Our findings also contribute to the conversation shared by both academia and the popular press regarding the realized 'globalization' of firms relative to the intermediate view, or ‘semiglobalization' perspective (Cairncross, 2001; Friedman, 1999, 2005; Ghemawat, 2003, 2005; Rugman and Verberke, 2004, 2007). Regionalization scholars argue that although MNEs are a driving force in globalization, with respect to the manner of increasing economic interdependence among national markets, data on the activities of MNEs show that few have actually achieved global scope themselves (Rugman and Verbeke, 2004). Our results advance that, in addition to the country-level effects, the geographic configuration of value creating 
activities across countries within a region does influence a firm's entry decision into one of the countries in the region for its R\&D activities. Our multilevel theory and empirical specifications enable us to address these apparently complex relationships between countries and regions where the former is nested into the latter. Thus, our findings confirm that regionalization theory and the semiglobalization view provide a new and valuable lens of inquiry into the recent geographic entry empirical patterns of innovative activity.

Our cross-classified multilevel analysis also contributes to the management literature, both theoretically and empirically. Theoretically, studies on regionalization and our multilevel theory introduced in the current study build on the very important mechanism that MNCs are nomadic, seeking location-specific advantages across countries nested within regions. In fact, the mobility of MNCs across countries is one of the fundamental building blocks of many theories in international business. As such, while countries nest within the regions, MNCs do not, suggesting that the phenomenon of interest is in a cross-classified rather than a nested structure. Empirically, therefore, testing a theory for the cross-classified multilevel phenomenon necessitates use of corresponding statistical techniques. Employing the regular techniques designed to analyze the nested structure would provide biased results. More specifically, employing the regular multilevel choice model designed to analyze a phenomenon with the nested structure would statistically limit the geographic scope of MNCs' operations to confinement within their home region precisely because of the nested structure of the statistical technique. As such, the statistical technique employed in the current study introduces a more advanced and appropriate statistical test for the management field to properly accommodate the fundamental theoretical and empirical nature of the phenomenon, and thereby, an opportunity to facilitate new and more complex multilevel theory building. 
We also offer that our theory and results make a contribution by addressing a 'big question' (Buckley and Ghauri, 2004) as we respond to Dunning's (1998, p. 46) call that 'the changing extent, character and geography of MNE activities...is demanding an explanation' by management scholars. We offer a theoretically grounded answer with a multilevel theory that draws on the regionalization theory and the semiglobalization perspective, normally recognized as content unique to the international management discipline (Ghemawat, 2003). Thus, we believe our study offers a new exchange in a now shared conversation between the technology management and international management literatures.

\section{Practical Implications}

There are several practical implications to our study. First, our theory and results show that firms organizing regionally through their downstream activities (commercialization) provides complementary assets to their upstream activities — specifically R\&D activities in a country within that region - allowing them to appropriate more from their innovations. Moreover, regional downstream commercialization activities can substitute for weak IPR regimes, thereby providing the firm with an alternative mechanism for protecting its intellectual property in weak IPR countries. Our identification of the firm-specific value appropriation capability and its relationship to intellectual property protection in different IPR environments should encourage managers to rethink countries they have previously avoided but want to enter with $R \& D$ activities to fuel their innovative processes. For example, firms faced a dilemma earlier if they wanted to enter a weak IPR protection country with country-specific factors not available anywhere else and that could substantially enhance their competitive advantage (e.g., the rainforest countries for tropical disease research) (Rugman and Verbeke, 1992). Should you swim upstream to risky waters? Our research offers an answer to that question: You should not unless 
you are equipped with the firm-specific value appropriation capability that you can substitute for the weak IPR protection of the country. This allows you to fearlessly swim upstream to risky waters.

Second, from a competitive dynamics perspective, firms need to be cautious to the situation where competitors with high levels of commercialization in a region could also collocate their R\&D activities. This would allow competitors to gain synergies and exclusive appropriation benefits. Therefore, the combination of $\mathrm{R} \& \mathrm{D}$ activity with commercialization activity might serve as a future barrier of entry that could help sustain a competitive advantage for competitors. Recognizing this potential condition, managers may work to safeguard their competitive position.

Third, while we show that entering regionally through commercialization activity can lead to more country-level R\&D activity, managers could consider increasing commercialization activities (and co-specialized DCAs) in regions where they have already entered with R\&D activity. This would provide two benefits of complementarity assets: intellectual property protection and synergies. This recommendation is particularly important if firms have already entered their R\&D activities in countries with weak IPR regimes.

\section{Opportunities for Future Research}

This study allows for several opportunities for future research. First, we use a single industry to test our theory. While there are a number of benefits to single-industry studies-for example, consistency in measurement and controlling for potential influences from industry structure (Ahuja et al., 2008) — there might be important differences across other industries. Thus, future research might consider testing our theory using different industries. Furthermore, future research might consider building on our theory by considering how different industry 
characteristics, such as munificence, influence regionalization theory, and the semiglobalization perspective. Second, we chose to focus our study on the internationalization of R\&D because of the recent geographic entry empirical patterns and its importance and susceptibility to intellectual property limitations in countries. There are, however, a number of different activities within the value chain that call for exploration in the domain of geographic entry using the upstream/downstream framework. These could include country sales or financing activities. Future studies could explore the geographic entry of these different activities by building and testing theory on how different activities could behave differently from R\&D. In addition, upcoming research could extend the discrete choice approach taken in the current study and consider among various choices a particular firm has to conduct its R\&D activities. ${ }^{\text {vii }}$

\section{CONCLUSION}

The starting point of our paper was the puzzling question, how do firms appropriate the value they create from their $R \& D$ activities in weak appropriability regime countries? To address this we develop a framework identifying how commercialization activities in a region help firms to develop a firm-specific value appropriation capability, which can be an alternative mechanism that firms may use to protect their intellectual property in weak IPR environments. We also find the firm-specific value appropriation capability in a substitutional relationship with the IPR regime of an environment, in line with Teece (1986). Our theory and results establish a new answer to the puzzling empirical pattern of geographic entry. Thus, some firms really are fearlessly swimming upstream to risky waters. 


\section{REFERENCES}

Ahuja, G., Lampert, C. M. and Tandon, V. (2008). 'Moving beyond Schumpeter: Management research on the determinants of technological innovation'. Academy of Management Annals, 2, 1-98.

Almeida, P. (1996). 'Knowledge sourcing by foreign multinationals: patent citation analysis in the U.S. semiconductor industry'. Strategic Management Journal, 17, 155-65.

Almeida, P. and Kogut, B. (1999). 'Localization of knowledge and the mobility of engineers in regional networks'. Management Science, 45, 905-17.

Antonakis, J., Bendahan, S., Jacquart, P. and Lalive, R. (2010). 'On making causal claims: A review and recommendations'. The Leadership Quarterly, 21, 1086-1120.

Arias, L. (2015a). 'Intel expands Costa Rica operations'. The Tico Times, 16 November. Available at: http://www.ticotimes.net/2015/11/16/intel-expands-costa-rica-operations (accessed 9 August 2016).

Arias, L. (2015b). 'Intel hiring for new Costa Rica operation'. The Tico Times, 18 November. Available at: http://www.ticotimes.net/2015/11/18/intel-is-hiring-engineers-for-newcosta-rica-business-unit (accessed 9 August 2016).

Arora, A. and Gambardella, A. (1990). 'Complementarity and external linkages: The strategies of the large firms in biotechnology'. Journal of Industrial Economics, 38, 361-79.

Arregle, J-L., Beamish, P. W. and Hébert, L. (2009). 'The regional dimension of MNEs' foreign subsidiary localization'. Journal of International Business Studies, 40, 86-107.

Arregle, J-L., Hébert, L. and Beamish, P. W. (2006). 'Mode of international entry: The advantages of multilevel methods'. Management International Review, 46, 597-618. 
Arregle, J-L., Miller, T. L., Hitt, M. A. and Beamish, P. W. (2013). 'Do regions matter? An integrated institutional and semiglobalization perspective on the internationalization of MNEs'. Strategic Management Journal, 34, 910-34.

Baum, J. A. C., Calabrese, T. and Silverman, B. S. (2000). 'Don't go it alone: Alliance network composition and startups' performance in Canadian biotechnology'. Strategic Management Journal, 21, 267-94.

Birkinshaw, J. (2000). Entrepreneurship in the Global Firm: Enterprise and Renewal. London, UK: Sage.

Browne, W. J. (2012). MCMC Estimation in MLwiN, v2.26. Centre for Multilevel Modelling. Bristol, UK: University of Bristol.

Buckley, P. J. and Casson, M. (1976). The Future of the Multinational Enterprise. London, UK: Macmillan.

Buckley, P. J. and Ghauri, P. N. (2004). 'Globalisation, economic geography and the strategy of multinational enterprises'. Journal of International Business Studies, 35, 81-98.

Cairncross, F. (2001). The Death of Distance: How the Communications Revolution is Changing our Lives. Boston, MA: Harvard Business School Press.

Cantwell, J. (1989). Technological Innovation and Multinational Corporations. Oxford, UK: Basil Blackwell.

Cantwell, J. (2009). 'Location and the multinational enterprise'. Journal of International Business Studies 40, 35-41.

Ceccagnoli, M., Graham, S. J., Higgins, M. J. and Lee, J. (2010). 'Productivity and the role of complementary assets in firms' demand for technology innovations'. Industrial and Corporate Change, 19, 839-69. 
Chakrabarti, A. and Mitchell, W. (2013). 'The persistent effect of geographic distance in acquisition target selection'. Organization Science, 24, 1805-826.

Cheng, J. L., Henisz, W. J., Roth, K. and Swaminathan, A. (2009). 'From the Editors: Advancing interdisciplinary research in the field of international business: Prospects, issues and challenges'. Journal of International Business Studies, 40, 1070-74.

Cohen, J., Cohen, P., West, S. G. and Aiken, L. S. (2013). Applied Multiple

Regression/Correlation Analysis for the Behavioral Sciences, 3rd edition. Mahwah, NJ: Lawrence Erlbaum.

Costa Rican Investment Promotion Agency. (2014). Intel will establish mega laboratory in Costa Rica for the validation of new products. PRNewswire. 10 June. Available at: http://www.prnewswire.com/news-releases/costa-rican-investment-promotion-agencyintel-will-establish-mega-laboratory-in-costa-rica-for-the-validation-of-new-products262618291.html (accessed 9 August 2016).

Coval, J. D. and Moskowitz, T. J. (2001). 'The geography of investment: Informed trading and asset prices'. Journal of Political Economy, 109, 811-41.

Danzon, P. M., Nicholson, S. and Pereira, N. S. (2005). 'Productivity in pharmaceuticalbiotechnology R\&D: The role of experience and alliances'. Journal of Health Economics, 24, 317-39.

Doz, Y.L. and Wilson, K. (2012). Managing Global innovation: Frameworks for Integrating Capabilities around the World. Boston, MA: Harvard Business Review Press.

Dunning, J. H. (1981). International Production and the Multinational Enterprise. London, UK: Allen \& Unwin. 
Dunning, J. H. (1998). 'Location and the multinational enterprise: A neglected factor?'. Journal of International Business Studies, 29, 45-66.

Dunning, J. H. (2000). 'The eclectic paradigm as an envelope for economic and business theories of MNE activity’. International Business Review, 9, 163-190.

Dunning, J. H. (2003). 'Some antecedents of internalization theory'. Journal of International Business Studies, 34, 108-15.

Dunning, J. H. and Lundan, S. M. (2008). Multinational Enterprises and the Global Economy. Cheltenham, UK: Edward Elgar.

Fleming, L. (2001). 'Recombinant uncertainty in technological search'. Management Science, 47, 117-32.

Flores, R. G. and Aguilera, R. V. (2007). 'Globalization and location choice: An analysis of US multinational firms in 1980 and 2000'. Journal of International Business Studies, 38, $1187-1210$.

Florida, R. (1997). 'The globalization of R\&D: Results of a survey of foreign-affiliated R\&D laboratories in the USA'. Research Policy, 26, 85-103.

Foss, K. and Foss, N. J. (2005). 'Resources and transaction costs: how property rights economics furthers the resource-based view'. Strategic Management Journal, 26, 541-53.

Freeman, C. (1987). Technology Policy and Economic Performance: Lessons from Japan. London, UK: Pinter Publishers.

Friedman, T. (1999). The Lexus and the Olive Tree. New York: Farrar, Straus and Giroux.

Friedman, T. (2005). The World is Flat: A Brief History of the Twenty-First Century. New York: Farrar, Straus and Giroux. 
Frost, T. S. (2001). 'The geographic sources of foreign subsidiaries' innovations'. Strategic Management Journal, 22, 101-23.

Ghemawat, P. (2001). 'Distance still matters'. Harvard Business Review, 79(8), 137-47.

Ghemawat, P. (2003). 'Semiglobalization and international business strategy'. Journal of International Business Studies, 34, 138-52.

Ghemawat, P. (2005). 'Regional strategies for global leadership'. Harvard Business Review, 83(12), 98-108.

Ghemawat, P. (2007). 'Managing differences: The central challenge of global strategy'. Harvard Business Review, 85(3), 58-68.

Gilman, D. (2010). The New Geography of Global Innovation. New York: Global Markets Institute/Goldman Sachs.

Girotra, K., Terwiesch, C. and Ulrich, K. T. (2007). 'Valuing R\&D projects in a portfolio: Evidence from the pharmaceutical industry'. Management Science, 53, 1452-66.

Goldstein, H. (2011). Multilevel Statistical Models, 4th edition. Chichester, U.K.: John Wiley \& Sons.

Goldstein, H., Browne, W. and Rasbash, J. (2002). 'Partitioning variation in multilevel models'. Understanding Statistics: Statistical Issues in Psychology, Education, and the Social Sciences, 1, 223-31.

Grant, R. M. (1996). 'Prospering in dynamically-competitive environments: Organizational capability as knowledge integration'. Organization Science, 7, 375-87.

Guo, S. and Fraser, M. W. (2010). 'Propensity score analysis: Statistical methods and applications.' Psychometrika 75, 775-77. 
Hejazi, W. (2007). 'Reconsidering the concentration of US MNE activity: Is it global, regional or national?'. Management International Review, 47(1): 5-27.

Helfat, C. E. (1997). 'Know-how and asset complementarity and dynamic capability accumulation: The case of R\&D’. Strategic Management Journal, 18, 339-60.

Helfat, C. E. and Lieberman, M. B. (2002). 'The birth of capabilities: Market entry and the importance of pre-history'. Industrial and Corporate Change, 11, 725-60.

Henderson, R. and Cockburn, I. (1996). 'Scale, scope, and spillovers: The determinants of research productivity in drug discovery'. RAND Journal of Economics, 27, 32-59.

Hess, A. M. and Rothaermel, F. T. (2011). 'When are assets complementary? Star scientists, strategic alliances, and innovation in the pharmaceutical industry'. Strategic Management Journal, 32, 895-909.

Hill, R. G. and Rang H. P. (Eds.) (2012). Drug Discovery and Development: Technology in Transition, 2nd edition. London UK: Elsevier/Churchill Livingstone.

Hitt, M. A., Beamish, P. W., Jackson, S. E. and Mathieu, J. E. (2007). 'Building theoretical and empirical bridges across levels: Multilevel research in management'. Academy of Management Journal 50, 1385-99.

Jaffe, A. B., Trajtenberg, M. and Henderson, R. (1993). 'Geographic localization of knowledge spillovers as evidenced by patent citations'. Quarterly Journal of Economics, 108, 57798.

JMS Special Issue Call for Papers. (2016). 'The Who, Where, What, and When of Market Entry'. Available at: http://www.socadms.org.uk/wp-content/uploads/Market-Entry-SI-Call.pdf (accessed 28 November 2016). 
Khanna, T., Kogan, J. and Palepu, K. (2006). 'Globalization and similarities in corporate governance: A cross-country analysis'. Review of Economics and Statistics, 88, 69-90.

Kim, H. E. and Pennings, J. M. (2009). 'Innovation and strategic renewal in mature markets: A study of the tennis racket industry'. Organization Science, 20, 368-83.

Kim, M. (2013). 'Many roads lead to Rome: Implications of geographic scope as a source of isolating mechanisms'. Journal of International Business Studies, 44, 898-921.

Kim, M. (2016). 'Geographic scope, isolating mechanisms, and value appropriation'. Strategic Management Journal, 37, 695-713.

Kim U. K. and Aguilera, R. V. (2015). 'The world is spiky: An internationalization framework for a semi-globalized world'. Global Strategy Journal, 5: 113-32.

Kogut, B. (1991). 'Country capabilities and the permeability of borders'. Strategic Management Journal, 12(summer special issue), 33-47.

Koza, M. P. and Lewin, A. Y. (1998). 'The co-evolution of strategic alliances.' Organization Science, 9, 255-64.

Leask, F. (2015). 'Pfizer inaugurates Center of Excellence in Precision Medicine in Chile with strong focus on genomics'. 9 July 2015. Available at: http://www.selectscience.net/industry-news/pfizer-inaugurates-center-of-excellence-inprecision-medicine-in-chile-with-strong-focus-ongenomics/?artID=37967\#sthash.0YjIKT84.dpuf (accessed 28 August 2016)

Leckie, G. (2013). Cross-classified multilevel models - Concepts. LEMMA VLE Module 12, 160. Available at: http://www.bristol.ac.uk/cmm/learning/online-course/ (accessed17 August 2016). 
Leckie, G. and Charlton, C. M. J. (2013). 'runmlwin: A program to run the MLwiN multilevel modeling software from within Stata'. Journal of Statistical Software, 52, 1-40.

Lippman, S. A. and Rumelt, R. P. (1982). 'Uncertain imitability: An analysis of interfirm differences under competition'. Bell Journal of Economics, 13: 418-38.

Liu, M. and La Croix, S. (2015). 'A cross-country index of intellectual property rights in pharmaceutical inventions'. Research Policy 44, 206-16.

Lu, J. W. (2002). 'Intra-and inter-organizational imitative behavior: Institutional influences on Japanese firms' entry mode choice'. Journal of International Business Studies 33, 19-37.

Lundvall B. 1992. National Systems of Innovation: Towards a Theory of Innovation and Interactive Learning. London, UK: Pinter Publishers.

Mahoney, J. T. and Pandian, J. R. (1992). 'The resource-based view within the conversation of strategic management'. Strategic Management Journal, 13: 363-80.

Maylay Mail Online. (2016). 'Apple to invest US\$1b in Vietnam data centre'. 17 March. Available at: http://www.themalaymailonline.com/money/article/apple-to-invest-us 1b-invietnam-data-centre (accessed 9 August 2016)

McNamara, G. and Vaaler, P. M. (2000). 'The influence of competitive positioning and rivalry on emerging market risk assessment'. Journal of International Business Studies, 31, 337 47.

Milgrom, P. and Roberts, J. (1995). 'Complementarities and fit strategy, structure, and organizational change in manufacturing'. Journal of Accounting and Economics, 19, $179-208$.

Mitchell, W. (1989). 'Whether and when? The probability and timing of incumbents' entry into emerging industrial subfields'. Administrative Science Quarterly 34: 208-30. 
Mitchell, W. (1991). 'Dual clocks: Entry order influences on incumbent and newcomer market share and survival when specialized assets retain their value'. Strategic Management Journal, 12, 85-100.

Nelson, R. R. (Ed). (1993). National Innovation Systems: A Comparative Analysis. New York: Oxford University Press.

Patel, P. and Vega, M. (1999). 'Patterns of internationalisation of corporate technology: Location vs. home country advantages'. Research Policy, 28, 145-55.

Pearce, R. D. (1999). 'Decentralised R\&D and strategic competitiveness: Globalised approaches to generation and use of technology in multinational enterprises (MNEs)'. Research Policy, 28, 157-78.

Petersen, M. A. (2004). Information: Soft and Hard. Unpublished working paper. Kellogg School of Management, Northwestern University, Evanston, IL and National Bureau of Economic Research, Cambridge, MA.

Petersen, M. A. and Rajan, R. G. (2002). 'Does distance still matter? The information revolution in small business lending'. Journal of Finance, 57, 2533-70.

Peterson, M. F., Arregle, J. L. and Martin, X. (2012). 'Multilevel models in international business research'. Journal of International Business Studies, 43, 451-57.

Pisano, G. (2006). 'Profiting from innovation and the intellectual property revolution'. Research Policy, 35, 1122-30.

Polanyi, M. (1958). Tacit Knowledge: Toward a Post-Critical Philosophy. Chicago: The University of Chicago Press. 
Polidoro, F. (2013). 'The competitive implications of certifications: The effects of scientific and regulatory certifications on entries into new technical fields'. Academy of Management Journal, 56, 597-627.

Qian, G., Li, L. and Rugman, A. M. (2013). 'Liability of country foreignness and liability of regional foreignness: Their effects on geographic diversification and firm performance'. Journal of International Business Studies, 44, 635-647.

Rasbash, J., Charlton, C., Browne, W. J., Healy, M. and Cameron, B. (2009). MLwIN Version 2.1. Centre for Multilevel Modelling. Bristol, UK: University of Bristol.

Raudenbush, S. W. and Bryk, A. S. (2002). Hierarchical Linear Models: Applications and Data Analysis Methods, 2nd edition. Thousand Oaks, CA: Sage.

Reuer, J. J. and Lahiri, N. (2013). 'Searching for alliance partners: Effects of geographic distance on the formation of R\&D collaborations'. Organization Science, 25: 283-98.

Rosenbaum, P. R. and Rubin, D. B. (1983). 'The central role of the propensity score in observational studies for causal effects'. Biometrika, 70, 41-55.

Rugman, A. M. (1981). Inside the Multinationals. New York: Columbia University Press.

Rugman, A. M. (2005). The Regional Multinationals. New York: Cambridge University Press.

Rugman, A. M. and Verbeke, A. (1992). 'A note on the transnational solution and the transaction cost theory of multinational strategic management'. Journal of International Business Studies, 23(4): 761-71.

Rugman, A. M. and Verbeke, A. (2004). 'A perspective on regional and global strategies of multinational enterprises'. Journal of International Business Studies, 35, 3-18. 
Rugman, A. M. and Verbeke, A. (2005). 'Towards a theory of regional multinationals: A transaction cost economics approach'. MIR: Management International Review, 45, 517.

Rugman, A. M. and Verbeke, A. (2007). 'Liabilities of regional foreignness and the use of firmlevel versus country-level data: A response to Dunning et al. (2007)'. Journal of International Business Studies, 38, 200-05.

Rumelt, R. R. (1984). 'Toward a strategic theory of the firm.' In Lamb, R. (Ed.), Competitive Strategic Management. Englewood Cliffs, NJ: Prentice-Hall, 556-70.

Snijders, T. A. B. and Bosker, R. J. (2012). Multilevel Analysis: An Introduction to Basic and Advanced Multilevel Modeling, 2nd edition. Thousand Oaks, CA: Sage.

Sorenson, O. and Stuart, T. E. (2001). 'Syndication networks and the spatial distribution of venture capital investments'. American Journal of Sociology, 106, 1546-88.

Sosa, M. L. (2009). 'Application-specific R\&D capabilities and the advantage of incumbents: Evidence from the anticancer drug market'. Management Science, 55, 1409-22.

Sosa, M. L. (2011). 'From old competence destruction to new competence access: Evidence from the comparison of two discontinuities in anticancer drug discovery'. Organization Science, 22, 1500-16.

Stieglitz, N. and Heine, K. (2007). 'Innovations and the role of complementarities in a strategic theory of the firm'. Strategic Management Journal, 28, 1-15.

Teece, D. J. (1975). The multinational corporation and the resource cost of international technology transfer. PhD. Dissertation, University of Pennsylvania, Philadelphia, PA. 
Teece, D. J. (1981) 'The market for know-how and the efficient international transfer of technology'. The Annals of the American Academy of Political and Social Science, 458: $81-96$.

Teece, D. J. (1986). 'Profiting from technological innovation: Implications for integration, collaboration, licensing and public policy'. Research Policy, 15, 285-305.

Teece, D. J. (2014). 'A dynamic capabilities-based entrepreneurial theory of the multinational enterprise'. Journal of International Business Studies, 45, 8-37.

Tripsas, M. (1997). 'Unraveling the process of creative destruction: Complementary assets and incumbent survival in the typesetter industry'. Strategic Management Journal 18(Special Issue), 119-42.

Tuyet, M. (2016). 'Hanoi to be Apple's database center of Asia'. Vietnam Economic Times, 16 March. Available at: http://vneconomictimes.com/article/vietnam-today/hanoi-to-beapple-s-database-center-of-asia (accessed 9 August 2016).

World Bank. (2015). World Development Indicators. Washington, D.C.: World Bank.

Wu, B., Wan, Z. and Levinthal, D. A. (2014). 'Complementary assets as pipes and prisms: Innovation incentives and trajectory choices'. Strategic Management Journal 35, 125778.

Zachary, M. A., Gianiodis, P. T., Payne, G. T. and Markman, G. D. (2015). 'Entry timing: Enduring lessons and future directions'. Journal of Management, 41, 1388-1415.

Zhao, M. (2006). 'Conducting R\&D in countries with weak intellectual property rights protection'. Management Science, 52, 1185-99. 
FIGURE 1

Value Chain in the Global Pharmaceutical Industry

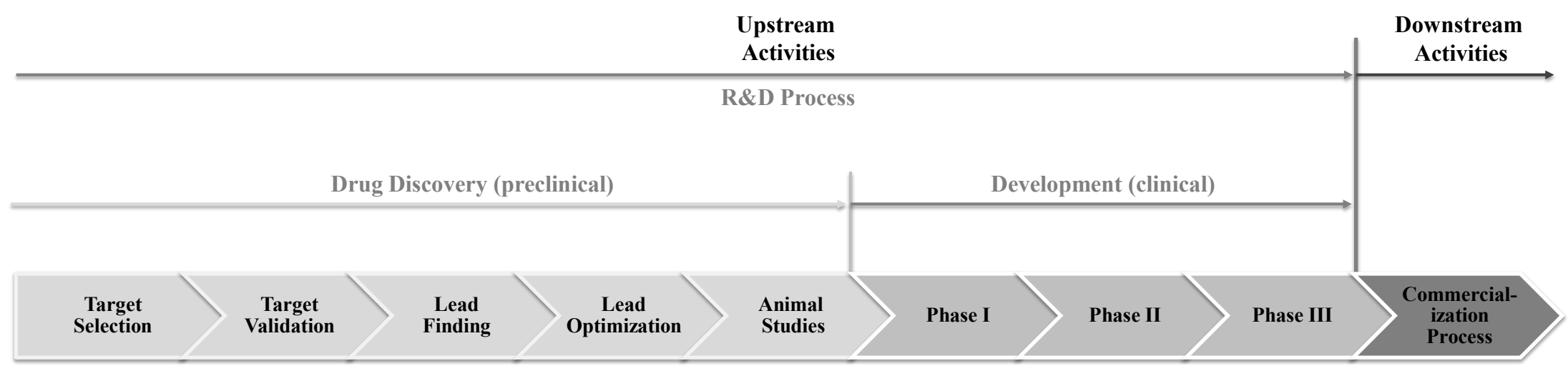

Adapted from Hill and Rang (2012) and Sosa (2009) 
FIGURE 2

Schematic Illustration of Firm Internationalization as a Cross-Classified Multilevel Phenomenon

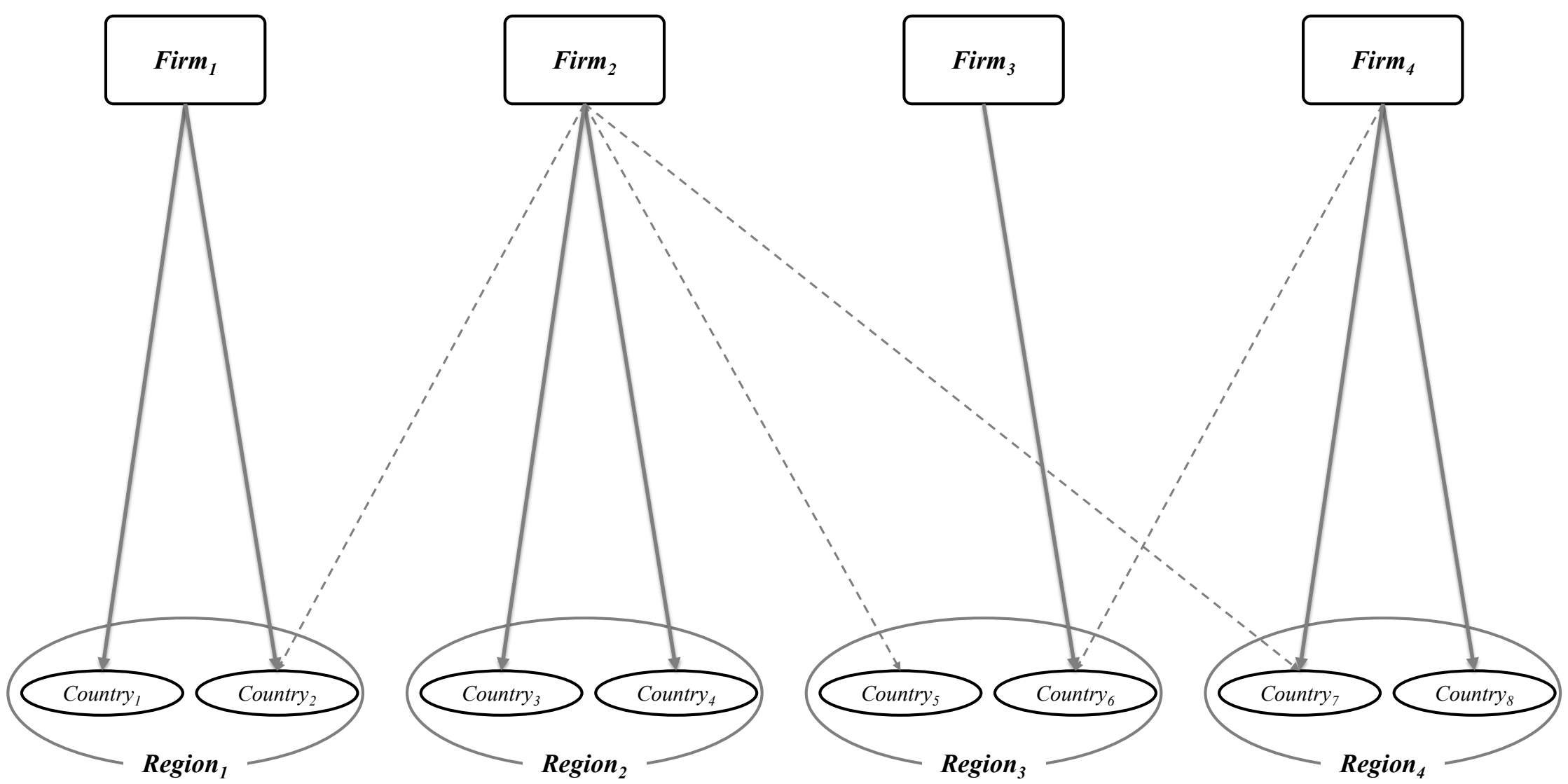


TABLE I

Constructs, Variables, and Measurements

\begin{tabular}{|c|c|c|c|c|}
\hline Variable & Level & Construct & Measurement & Source \\
\hline Dependent & $\begin{array}{l}\text { Firm- } \\
\text { Country }\end{array}$ & $\begin{array}{l}\mathrm{R} \& \mathrm{D} \text { activity of a firm } \\
\text { in a country }\end{array}$ & $\begin{array}{l}\text { A binary indicator equal to } 1 \text { if the firm } \\
\text { conducted drug discovery and } \\
\text { development activities in the particular } \\
\text { country, } 0 \text { otherwise }\end{array}$ & AdisInsight \\
\hline \multirow[t]{2}{*}{ Independent } & $\begin{array}{l}\text { Firm- } \\
\text { Region }\end{array}$ & $\begin{array}{l}\text { Prior commercialization } \\
\text { activity of a firm in a } \\
\text { region }^{\dagger}\end{array}$ & $\begin{array}{l}\text { A binary indicator equal to } 1 \text { if the firm } \\
\text { had launched a drug in the region during } \\
\text { the prior period, } 0 \text { otherwise }\end{array}$ & AdisInsight \\
\hline & Region & $\begin{array}{l}\text { Intellectual property } \\
\text { right protection }\end{array}$ & $\begin{array}{l}\text { Pharmaceutical IP Protection (PIPP) } \\
\text { index of the region (GDP weighted) }\end{array}$ & $\begin{array}{l}\text { Liu and La } \\
\text { Croix }(2015)\end{array}$ \\
\hline \multirow[t]{10}{*}{ Control } & Firm & Firm's slack resources & $\begin{array}{l}\text { Current ratio-a firm's current assets } \\
\text { divided by its current liabilities }\end{array}$ & Compustat \\
\hline & Firm & R\&D intensity ${ }^{\dagger}$ & R\&D expenditure divided by assets & Compustat \\
\hline & Firm & Firm size $^{\dagger}$ & Natural logarithm of assets & \\
\hline & Firm & $\begin{array}{l}\text { Firm's total R\&D } \\
\text { activity }\end{array}$ & $\begin{array}{l}\text { The number of drug discovery and } \\
\text { development activities of the firm }\end{array}$ & AdisInsight \\
\hline & Country & Patenting activity & $\begin{array}{l}\text { Natural logarithm of the number of } \\
\text { patent applications in the country }\end{array}$ & $\begin{array}{l}\text { World Bank } \\
(2015)\end{array}$ \\
\hline & Country & GDP growth & $\begin{array}{l}\text { Gross domestic product (GDP) growth } \\
\text { (annual \%) }\end{array}$ & $\begin{array}{l}\text { World Bank } \\
(2015)\end{array}$ \\
\hline & Country & $\begin{array}{l}\text { Country's total R\&D } \\
\text { activity }^{\dagger}\end{array}$ & $\begin{array}{l}\text { The number of drug discovery and } \\
\text { development activities in the country }\end{array}$ & AdisInsight \\
\hline & $\begin{array}{l}\text { Firm- } \\
\text { Country }\end{array}$ & $\begin{array}{l}\text { Prior commercialization } \\
\text { activity of a firm in a } \\
\text { country }^{\dagger}\end{array}$ & $\begin{array}{l}\text { A binary indicator equal to } 1 \text { if the firm } \\
\text { had launched a drug in the particular } \\
\text { country during the prior period, } 0 \\
\text { otherwise }\end{array}$ & AdisInsight \\
\hline & $\begin{array}{l}\text { Firm- } \\
\text { Country }\end{array}$ & $\begin{array}{l}\text { Prior } R \& D \text { activity of a } \\
\text { firm in a country }{ }^{\dagger}\end{array}$ & $\begin{array}{l}\text { A binary indicator equal to } 1 \text { if a firm } \\
\text { had conducted drug discovery and } \\
\text { development activities in the particular } \\
\text { country during the prior period, } 0 \\
\text { otherwise }\end{array}$ & AdisInsight \\
\hline & $\begin{array}{l}\text { Firm- } \\
\text { Region }\end{array}$ & $\begin{array}{l}\text { Prior R\&D activity of a } \\
\text { firm in a region }{ }^{\dagger}\end{array}$ & $\begin{array}{l}\text { A binary indicator equal to } 1 \text { if a firm } \\
\text { had conducted drug discovery and } \\
\text { development activities in the region } \\
\text { during the prior period, } 0 \text { otherwise }\end{array}$ & AdisInsight \\
\hline
\end{tabular}

$\uparrow:$ lagged 
TABLE II

Descriptive Statistics and Correlations

\begin{tabular}{|c|c|c|c|c|c|c|c|c|c|c|c|c|c|c|c|c|}
\hline & Variables & Mean & SD & (1) & (2) & (3) & (4) & (5) & (6) & (7) & (8) & (9) & (10) & (11) & (12) & (13) \\
\hline (1) & Firm-Country: R\&D activity of a firm in a country & 0.12 & 0.32 & 1 & & & & & & & & & & & & \\
\hline (2) & Firm: Firm slack resources & 3.56 & 2.47 & -0.11 & 1 & & & & & & & & & & & \\
\hline (3) & Firm: R\&D intensity & 0.22 & 0.27 & -0.11 & 0.38 & 1 & & & & & & & & & & \\
\hline (4) & Firm: Firm size & 6.61 & 2.37 & 0.24 & -0.46 & -0.65 & 1 & & & & & & & & & \\
\hline (5) & Firm: Firm's total R\&D activity & 128.04 & 228.11 & 0.31 & -0.28 & -0.2 & 0.56 & 1 & & & & & & & & \\
\hline (6) & Country: Patenting activity & 6.14 & 4.30 & 0.27 & 0.00 & 0.00 & 0.00 & 0.00 & 1 & & & & & & & \\
\hline (7) & Country: GDP growth & 4.90 & 2.83 & -0.15 & 0.00 & 0.00 & 0.00 & 0.00 & 0.03 & 1 & & & & & & \\
\hline (8) & Country: Country's total R\&D activity & 278.02 & 1478.11 & 0.28 & -0.01 & -0.02 & 0.02 & 0.00 & 0.26 & -0.15 & 1 & & & & & \\
\hline (9) & Firm-Country: Prior commercialization activity of a firm in a country & 0.09 & 0.28 & 0.43 & -0.13 & -0.12 & 0.26 & 0.35 & 0.24 & -0.13 & 0.22 & 1 & & & & \\
\hline (10) & Firm-Country: Prior R\&D activity of a firm in a country & 0.09 & 0.29 & 0.71 & -0.11 & -0.10 & 0.22 & 0.30 & 0.26 & -0.16 & 0.31 & 0.51 & 1 & & & \\
\hline (11) & Firm-Region: Prior R\&D activity of a firm in a region & 0.27 & 0.45 & 0.45 & -0.16 & -0.13 & 0.31 & 0.38 & 0.24 & -0.05 & 0.17 & 0.40 & 0.52 & 1 & & \\
\hline (12) & Firm-Region: Prior commercialization activity of a firm in a region & 0.23 & 0.42 & 0.38 & -0.22 & -0.22 & 0.41 & 0.47 & 0.19 & -0.03 & 0.11 & 0.56 & 0.41 & 0.61 & 1 & \\
\hline (13) & Region: Intellectual property right protection & 2.11 & 1.02 & 0.28 & 0.01 & 0.00 & -0.01 & 0.00 & 0.31 & -0.22 & 0.32 & 0.25 & 0.30 & 0.33 & 0.26 & 1 \\
\hline
\end{tabular}

Correlations greater than 0.02 are statistically significant at $p \leq 0.01 . n=16,204$. 
TABLE III

Results of Cross-Classified Multilevel Logistic Regression Predicting Firm R\&D Activity within a Country

\begin{tabular}{|c|c|c|c|c|c|c|}
\hline \multirow{2}{*}{$\frac{\text { Variables }}{\text { Firm: Firm slack resources }}$} & \multicolumn{2}{|l|}{ Model 1} & \multicolumn{2}{|l|}{ Model 2} & \multicolumn{2}{|l|}{ Model 3} \\
\hline & 0.09 & $(0.07)$ & 0.09 & $(0.06)$ & 0.09 & $(0.07)$ \\
\hline Firm: R\&D intensity & 0.65 & $(0.69)$ & 0.61 & $(0.75)$ & 0.59 & $(0.78)$ \\
\hline Firm: Firm size & $0.33 * * *$ & $(0.10)$ & $0.33 * *$ & $(0.11)$ & $0.33 * *$ & $(0.11)$ \\
\hline Firm: Firm's total R\&D activity & $0.00 * * *$ & $(0.00)$ & $0.00 * * *$ & $(0.00)$ & $0.00 * * *$ & $(0.00)$ \\
\hline Country: Patenting activity & $0.24 * * *$ & $(0.03)$ & $0.23 * * *$ & $(0.03)$ & $0.15^{* * *}$ & $(0.04)$ \\
\hline Country: GDP growth & $-0.18 * * *$ & $(0.04)$ & $-0.17 * * *$ & $(0.04)$ & $-0.15 * * *$ & $(0.04)$ \\
\hline Country: Country’s total R\&D activity & $0.00 *$ & $(0.00)$ & $0.00 *$ & $(0.00)$ & 0.00 & $(0.00)$ \\
\hline Firm-Country: Prior commercialization activity of a firm in a country & $-0.50 * * *$ & $(0.14)$ & $-0.52 * * *$ & $(0.14)$ & $-0.46^{* *}$ & $(0.15)$ \\
\hline Firm-Country: Prior R\&D activity of a firm in a country & $3.86^{* * *}$ & $(0.14)$ & $3.85 * * *$ & $(0.14)$ & $3.85^{* * *}$ & $(0.14)$ \\
\hline Firm-Region: Prior R\&D activity of a firm in a region & $0.36^{* *}$ & $(0.13)$ & $0.34 * *$ & $(0.13)$ & $0.37 * *$ & $(0.13)$ \\
\hline Firm-Region: Prior commercialization activity of a firm in a region & & & 0.03 & $(0.14)$ & $0.37+$ & $(0.21)$ \\
\hline Region: Intellectual property right (IPR) protection & & & $0.39 *$ & $(0.17)$ & & \\
\hline Second quartile group of IPR protection $\left(\mathrm{Q}_{2}\right)$ & & & & & 0.35 & $(0.33)$ \\
\hline Third quartile group of IPR protection $\left(\mathrm{Q}_{3}\right)$ & & & & & $1.10^{* *}$ & $(0.37)$ \\
\hline Fourth quartile group of IPR protection $\left(\mathrm{Q}_{4}\right)$ & & & & & $1.85 * * *$ & $(0.34)$ \\
\hline Prior commercialization activity of a firm in a region $\times \mathrm{Q}_{2}$ & & & & & -0.09 & $(0.27)$ \\
\hline Prior commercialization activity of a firm in a region $\times \mathrm{Q}_{3}$ & & & & & $-0.61 *$ & $(0.28)$ \\
\hline Prior commercialization activity of a firm in a region $\times \mathrm{Q}_{4}$ & & & & & $-0.61 *$ & $(0.24)$ \\
\hline Constant & $-8.49 * * *$ & $(0.89)$ & $-9.31 * * *$ & $(1.00)$ & $-8.79 * * *$ & $(1.02)$ \\
\hline Random-Effect Variance (firm-level) & $2.45^{* * *}$ & & $2.44 * * *$ & & $2.49^{* * *}$ & \\
\hline Random-Effect Variance (regional-level) & 0.58 & & 0.37 & & $1.79+$ & \\
\hline Random-Effect Variance (country-level ) & $0.94 * * *$ & & $0.95^{* * *}$ & & $0.58 * * *$ & \\
\hline Variance Partition Coefficient (firm-level) & 0.34 & & 0.35 & & 0.31 & \\
\hline Variance Partition Coefficient (regional-level) & 0.08 & & 0.05 & & 0.22 & \\
\hline Variance Partition Coefficient (country-level) & 0.13 & & 0.13 & & 0.07 & \\
\hline Variance Partition Coefficient (observation) & 0.45 & & 0.47 & & 0.40 & \\
\hline Observations & 16,204 & & 16,204 & & 16,204 & \\
\hline
\end{tabular}

The parameter point estimates and standard errors (reported in parentheses) are the means and standard deviations of the MCMC parameter chains (see Appendix A for details); ${ }^{\dagger} p<.10 ; * p<.05 ; * * p<.01 ;{ }^{* * *} p<.001$; IPR protection level: $\mathrm{Q}_{1}$ : low; $\mathrm{Q}_{2}$ : moderate low; $\mathrm{Q}_{3}$ : moderate high; $\mathrm{Q}_{4}$ : high. 


\section{APPENDIX A: ANALYSIS DETAILS}

Let $\pi_{i, j k}$ denote the probability that firm $i(i=1, \ldots, N)$ innovates in country $j(j=1, \ldots, J)$ in region $k(k=1, \ldots, K)$. We separate the firm index from the country and region indices by a comma to indicate their cross-classification as opposed to the standard hierarchical case where each firm operates in a single country and region. The cross-classified multilevel logistic regression model for the log-odds of innovating is as follows:

$$
\operatorname{logit}\left(\pi_{i, j k}\right) \equiv \log \left(\frac{\pi_{i, j k}}{1-\pi_{i, j k}}\right)=\mathbf{x}_{i, j k}^{\prime} \boldsymbol{\beta}+f_{i}+c_{j k}+r_{k}
$$

where $\mathbf{x}_{i, j k}$ is a vector of firm-, country-, and regional-level covariates with regression coefficient vector $\boldsymbol{\beta}$. Exponentiating the regression coefficients results in odds ratios. The $f_{i}, c_{j k}$ and $r_{k}$ are random-intercept effects representing remaining unobserved firm, country, and regional influences. These effects are assumed mutually independent, independent of the covariates, and normally distributed with zero means and constant variances $f_{i} \sim N\left(0, \sigma_{f}^{2}\right)$, $c_{j k} \sim N\left(0, \sigma_{c}^{2}\right)$, and $r_{k} \sim N\left(0, \sigma_{r}^{2}\right)$. The random effect variances $\sigma_{f}^{2}, \sigma_{c}^{2}$ and $\sigma_{r}^{2}$ summarize the extent of unobserved heterogeneity across firms, countries, and regions, respectively. These variances are typically rescaled to be Variance Partition Coefficients (VPCs) defined as the proportions of the total residual variance derived from the latent response formulation of the

model (Goldstein et al., 2002). Specifically, each variance is divided by $\sigma_{f}^{2}+\sigma_{c}^{2}+\sigma_{r}^{2}+3.29$, where 3.29 is the variance of the standard logistic distribution.

We fit all models by Markov Chain Monte Carlo (MCMC) methods as implemented in the MLwiN software (Browne, 2012; Rasbash et al., 2009). We call MLwiN from within Stata using the user-written runmlwin command (Leckie and Charlton, 2013). We specify diffuse (vague, flat, or minimally informative) prior distributions for all parameters. We obtain starting 
values from naïve two-level models fitted by maximum likelihood estimation that ignore the country-level and regional-level clustering. We run all models using a burn-in period of 2,500 iterations and a monitoring period of 25,000 iterations. Visual assessments of the parameter chains and standard MCMC convergence diagnostics suggest that the length of these periods is sufficient. Quantile-quantile plots of the predicted random effects confirm normality assumptions are reasonable. We report the posterior means and standard deviations (SDs) of the 25,000 monitoring iterations. These quantities are analogous to the parameter estimates and standard errors from a frequentist analysis. We report $p$-values calculated from these quantities in the conventional way, therefore $p$-values for the variance components are approximate due to the non-normal sampling distributions of these parameters. 
TABLE AI: List of Countries and Regions

\begin{tabular}{|c|c|c|c|}
\hline Countries & Regions & Countries & Regions \\
\hline Australia & Australia and New Zealand & Chile & South America \\
\hline New Zealand & Australia and New Zealand & Colombia & South America \\
\hline Cuba & Caribbean & Ecuador & South America \\
\hline Dominican Republic & Caribbean & Paraguay & South America \\
\hline Haiti & Caribbean & Peru & South America \\
\hline Jamaica & Caribbean & Uruguay & South America \\
\hline Trinidad and Tobago & Caribbean & Venezuela & South America \\
\hline Costa Rica & Central America & Bangladesh & South-Central Asia \\
\hline El Salvador & Central America & India & South-Central Asia \\
\hline Guatemala & Central America & Iran & South-Central Asia \\
\hline Honduras & Central America & Kazakhstan & South-Central Asia \\
\hline Mexico & Central America & Kyrgyzstan & South-Central Asia \\
\hline Nicaragua & Central America & Nepal & South-Central Asia \\
\hline Panama & Central America & Pakistan & South-Central Asia \\
\hline Kenya & Eastern Africa & Sri Lanka & South-Central Asia \\
\hline Madagascar & Eastern Africa & Uzbekistan & South-Central Asia \\
\hline Malawi & Eastern Africa & Cambodia & South-Eastern Asia \\
\hline Mozambique & Eastern Africa & Indonesia & South-Eastern Asia \\
\hline Tanzania & Eastern Africa & Laos & South-Eastern Asia \\
\hline Uganda & Eastern Africa & Malaysia & South-Eastern Asia \\
\hline Zambia & Eastern Africa & Myanmar & South-Eastern Asia \\
\hline Zimbabwe & Eastern Africa & Philippines & South-Eastern Asia \\
\hline China & Eastern Asia & Singapore & South-Eastern Asia \\
\hline Japan & Eastern Asia & Thailand & South-Eastern Asia \\
\hline South Korea & Eastern Asia & Vietnam & South-Eastern Asia \\
\hline Belarus & Eastern Europe & South Africa & Southern Africa \\
\hline Bulgaria & Eastern Europe & Croatia & Southern Europe \\
\hline Czech Republic & Eastern Europe & Greece & Southern Europe \\
\hline Hungary & Eastern Europe & Italy & Southern Europe \\
\hline Moldova & Eastern Europe & Portugal & Southern Europe \\
\hline Poland & Eastern Europe & Serbia & Southern Europe \\
\hline Romania & Eastern Europe & Spain & Southern Europe \\
\hline Russia & Eastern Europe & Burkina Faso & Western Africa \\
\hline Slovak Republic & Eastern Europe & Gambia & Western Africa \\
\hline Ukraine & Eastern Europe & Ghana & Western Africa \\
\hline Cameroon & Middle Africa & Ivory Coast & Western Africa \\
\hline Congo & Middle Africa & Niger & Western Africa \\
\hline Gabon & Middle Africa & Nigeria & Western Africa \\
\hline Algeria & Northern Africa & Senegal & Western Africa \\
\hline Egypt & Northern Africa & Togo & Western Africa \\
\hline Libya & Northern Africa & Armenia & Western Asia \\
\hline Morocco & Northern Africa & Cyprus & Western Asia \\
\hline Sudan & Northern Africa & Iraq & Western Asia \\
\hline Tunisia & Northern Africa & Israel & Western Asia \\
\hline Canada & Northern America & Jordan & Western Asia \\
\hline United States & Northern America & Kuwait & Western Asia \\
\hline Denmark & Northern Europe & Lebanon & Western Asia \\
\hline Estonia & Northern Europe & Oman & Western Asia \\
\hline Finland & Northern Europe & Saudi Arabia & Western Asia \\
\hline Iceland & Northern Europe & Syria & Western Asia \\
\hline Ireland & Northern Europe & Turkey & Western Asia \\
\hline Latvia & Northern Europe & United Arab Emirates & Western Asia \\
\hline Lithuania & Northern Europe & Austria & Western Europe \\
\hline Norway & Northern Europe & Belgium & Western Europe \\
\hline Sweden & Northern Europe & France & Western Europe \\
\hline United Kingdom & Northern Europe & Germany & Western Europe \\
\hline Argentina & South America & Luxembourg & Western Europe \\
\hline Bolivia & South America & Netherlands & Western Europe \\
\hline Brazil & South America & Switzerland & Western Europe \\
\hline
\end{tabular}

Note: 118 countries in 18 regions; we employ the M49 standard or the United Nations Statistics Division's (UNSD) 'Standard country or area codes for statistical use (M49)' when classifying countries into the 18 regions. 


\section{NOTES}

${ }^{\mathrm{i}}$ Teece (1986) defines co-specialized assets as the most specific and tailored assets to the innovation, where specialized assets are less extreme in their degree of specialization.

ii The combination of upstream activity with DCAs is synergistic to both, meaning that complementarity exists as raising one activity increases the return to raising the other activity (Milgrom and Roberts, 1995). Moreover, the authors (p. 183) clarify that 'complementarity is symmetric: If doing more of activity $a$ raises the value of increases in activity $b$, then increasing $b$ also raises the value of increasing $a$.'

iii We follow the definition provided by Petersen and Rajan (2002, p. 2533) where, 'By soft information, we mean something similar to what is termed "tacit" information (see Polanyi (1958)-information that is hard to communicate to others, let alone capture in written documents'.

iv We employ the M49 standard or the United Nations Statistics Division's (UNSD) 'Standard country or area codes for statistical use (M49)'.

${ }^{\mathrm{v}}$ We thank an anonymous reviewer for this suggestion.

${ }^{v i}$ Propensity score matching is a method estimates the average treatment effect from observed data by assessing the differences between observed and potential outcomes for each subject. The potential outcomes are assessed by using the average of outcomes of similar subjects that receive the other treatment level. In our case, we used a minimum matching of four firms. Firms were required to match using a caliper matching method (Guo and Fraser, 2010). Calipers represent the absolute distance of propensity scores between two cases. In our case, we specified that each match had to have a caliper less than 0.10 . This indicates that our matching requires differences to be less than a tenth of a standard deviation of the sample estimated propensity scores. This is well below Rosenbaum and Rubin (1983)'s recommendation of 0.25-which is also suggested by Guo and Fraser (2010). We get similar results if we relax this constraint to their recommended level of 0.25 .

${ }^{\text {vii }}$ We thank an anonymous reviewer for this suggestion. 